Savunma Bilimleri Dergisi

The Journal of Defense Sciences

Kasim/Nov 2018, Cilt/Volume 17, Say1/Issue 2.

ISSN (Bas1l1) : 1303-6831 ISSN (Online): 2148-1776

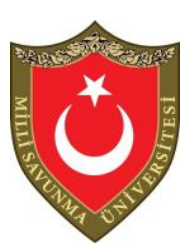

\title{
Yeni Arşiv Belgeleri Işığında Türk Askerî Havacılığının Doğuşu (1911-1912)
}

\author{
Deniz KURT* $^{*}$ ve Erdal KORKMAZ ${ }^{* *}$ \\ $\ddot{O} z$
}

1910 yılında Fransa'da düzenlenen Picardie Manevralarında ilk kez uçağın tatbiki anlamda kullanımı, dünya devletlerini olduğu kadar Osmanlı Devletini de havacılık teşkilatını kurma, uçak tedarik etme ve ordu mensuplarına pilotaj eğitimi verilmesi konularına yöneltmiştir. Bu hedef ve amaçlar doğrultusunda yapılan incelemeler devam ederken, Trablusgarp Harbinde Italyanların ilk kez uçak kullanması Osmanlı Devleti'ndeki uçak tedarik ve kurumsallaşma çalı̧̧malarını hızlandırmıştır. Bu kapsamda, havacılık faaliyetlerinin organize edilmesi için Harbiye Nazırliğ tarafindan bir Tayyarecilik Komisyonu ile Tayyare Mektebi ve Merkezi kurulması amacıyla çalışmalar başlatılmıştır.

Osmanl ordusu bünyesinde Hava Kuvvetlerinin ilk teşkilatlanma sürecine ilişkin bugüne kadar pek çok çalışmanın yapılmış olduğu görülmektedir. Bu alandaki çalışmalarda, Türk havacılı̆̆ının kuruluş sürecinde çok önemli görevler ve çalışmalar yapan Kurmay Yarbay Süreyya (İlmen) Bey başkanlığında oluşturulan "Havacılık Komisyonu”nun Türk askerî havacılığının ilk teşkilatı olduğu ve Tayyare Komisyonu'nun 1 Haziran 1911 tarihinde teşkil edildiği görüşü öne sürülmüştür.

Bu görüşü ifade eden yaylmlar, Kurmay Yarbay Süreyya (İlmen) Bey tarafindan hazırlanan ve Genelkurmay ATASE Arşivinde yer alan rapor ile yine Süreyya İmen'e ait olan "Türkiye'de Tayyarecilik ve Balonculuk Tarihi" adl eseri kaynak olarak göstermişlerdir. Ancak Kurmay Yarbay Süreyya Ilmen'in raporu ve

* Hv.Öğ.Yb., Hava Kuvvetleri Komutanlığı Tarihçe Şube Müdürlüğü, Ankara Üniversitesi İnkılap Tarihi Enstitüsü Doktora Öğrencisi, E-posta.: denı.kurt@hvkk.tsk.tr

** Tarih Uzmanı, Hava Kuvvetleri Komutanlı̆̆ Tarihçe Şube Müdürlüğü, Ankara Üniversitesi İnkılap Tarihi Enstitüsü Doktora Öğrencisi, E-posta.: e.korkmaz@hvkk.tsk.tr

Geliş Tarihi/Received:06.08.2018

Kabul Tarihi/Accepted:17.08.2018 
eserinde, Tayyare Komisyonunun kuruluşu ile ilgili tarih vermemesine rağmen, havacılı tarihi ile ilgili yapılan çalışmalarda Tayyare Komisyonu'nun kuruluş tarihi olarak 1 Haziran 1911 verilmiştir.

Bu makalede, Hava Kuvvetlerinin kuruluşu olarak kabul edilen ilk Tayyare Komisyonu'nun 1 Haziran 1911 tarihinde Kurmay Yarbay Süreyya İlmen'in de görev yaptığl, Erkan-ı Harbiye Dairesi 2'nci Şubesinde görevli Kurmay Yarbay Ismail Bey başkanlı̆̆ında kurulduğu, arşiv belgeleri çerçevesinde belirlenmiştir. Makalede Türk havacıllğııın kuruluş sürecinin en önemli simalarından olan Kurmay Yarbay Süreyya (İlmen) Bey başkanlı̆̆ında kurulan komisyonun Mart 1912'de, Tayyare Mektep ve Merkezinin kurulması maksadiyla oluşturulduğu da ayrıntılı bir şekilde ele alınmıştır. Bu çalışma ile Türk askerî havacılı̆̆ının kuruluşu yeni belgeler ışığında yeniden değerlendirilmektedir.

Anahtar Kelimeler: Tayyare, Kuruluş, Pilot, Havacılık, Teşkilat.

\title{
The Birth of Turkish Military Aviation within the Extent of New Archive Documents (1911-1912)
}

\begin{abstract}
In 1910 during the Picardie Maneuvers, the first usage of aircraft on the field had an impact on all countries as well as Ottoman State, in order to establish an aviation organization, procure aircraft and train its forces in pilotage. While the research on this aim and purpose was going on, Italians has used the first aircraft on the theatre in Tripoli War, accelerated the aircraft procurement and institutional developments in Ottoman State. In this scope, establishment of Aviation Commission and Aircraft School and Center had commenced by Ministry of War in order to organize aviation activities.

It is observed that there are so many studies on the first establishment period of Air Forces in Ottoman Army. In all studies on this field, it was stated that "Aircraft Commission" established under Staff Lt.Col. Süreyya Ilmen, was the first organization which was founded in 1 June 1911. Publications centered on this idea used the same source "Aircraft and Balloon History in Turkey" which was written by Süreyya İlmen in Turkish General Staff Archives. Although Süreyya Ilmen stated
\end{abstract}


no date in his reports or in his book, all studies prepared upon this subject stated 1 June 1911 as the day which Aircraft Commission founded.

In this article, it is clarified using new archive documents that Aircraft Commision was not founded by Süreyya Ilmen, instead first commission was founded in 1 June 1911 under Staff Lt.Col. Ismail Bey who was assigned to 2'nd Branch of Department of War. In the study, it was explained in details that the commission founded under Süreyya Ilmen for the establishment of "Aircraft School and Center" in March 1912. With this study the birth of Turkish Military Aviation was brought up with new documents.

In this article, the first Tayyare Commission which was considered as the foundation of the Air Force, was established on the basis of archival documents established by Chief of Staff Colonel Ismail Bey, who served as Chief of Staff Colonel Süreyya Ilmen at the 2'nd point of Erkan-ı Harbiye Dairesi on 1 June 1911. It was discussed in detail that the commission established under the presidency of Staff Colonel Sureyya (Ilmen) Bey, who is one of the most important figures in the establishment period of the Turkish aviation, was formed in March 1912 with the aim of establishing the Tayyare School and Center. With this study, the establishment of Turkish Military Aviation is being reevaluated in the light of new documents.

Keywords: Aircraft, Establishment, Pilot, Aviation, Organization.

\section{Giriş}

20.nci Yüzyılın başında dünyada havacılık adına meydana gelen gelişmeler, Osmanlı Devleti tarafından yakından takip edilmiştir. Başlangıç aşamasında Avrupa'da balonların hava ulaşımı ve posta nakli alanlarında kullanılması ve sonrasında askerî maksatlı olarak havacılığın gündeme gelmesi Osmanlı idarecilerinin dikkatlerini bu yöne çevirmelerine yol açmıştır.

Osmanlı Devleti tarafından havacılığa ilişkin başlatılan çalışmalar batıdaki havacılık ile ilgili gelişmelerin askerî ataşeler aracılığı ile tespit, teşhis ve raporlanması ile hızlanmış ve şekillenmiştir. Trablusgarp ve Balkan Savaşları bu alandaki çalışmaların gereğini ve aciliyetini ortaya çıkarmıştır. Devlet kurumlarının 
bu konudaki reaksiyonu ile Osmanlı Ordusu bünyesinde havacılık teşkilatının kuruluş süreci başlatılmıştır.

1909 yılı içerisinde, Louis Bleriot adlı Fransız pilotun gerçekleştirdiği başarılı uçuşlar (İhsanoğlu, 1995: s.497-568) Avrupa'da uçak üretimi ve kullanımını hızla artırmaya başlamıştır. Kısa bir süre sonra ise uçak üreticileri, uçaklarının tanıtımını yapmak ve yeni hava araçlarını pazarlamak amacıyla dünyanın değişik ülkelerinde çeşitli hava gösterileri gerçekleştirmeye başlamıştır. $\mathrm{Bu}$ gösterilerden biri de İstanbul'da yapılmıştır. Osmanlı Harbiye Nezareti; 31 Mart İsyanının bastırılması ve ülkede asayişin sağlanması sonrasında geliri Hareket Ordusu'nun şehit ve yaralı ailelerine verilmek üzere bir hava gösterisi düzenlenmesi için Birinci, İkinci ve Üçüncü Ordular Müfettişi Mahmut Şevket Paşa'nın girişimleri ile Fransız baloncu Baron Hanri Delormo ile Mösyö Ernest Barbout'u İstanbul'a davet etmiştir. Hareket Ordusu Komutanlığı tarafından 20 Mayıs 1909 tarihinde Dâhiliye Nezaretine gönderilen yazı ile bu konuda gerekli iznin verilmesi istenmiştir. Dâhiliye Nezareti de durumu Sadaret makamına bir tezkire ile bildirmiştir. Üstelik baloncular, hava gösterisinin bütün masraflarını kendilerinin karşılayacağını taahhüt etmiş̦tir (BOA, BEO, Harbiye No.: 266696, 11 Mayıs 1325/24 May1s 1909; Kline, 2002: s.50). Bu talepler üzerine Sadaret makamından Hareket Ordusu Komutanlığına gönderilen 27 Mayıs 1909 tarihli cevabi yazı ile Hanri Delormo ve Ernest Barbout'a 15 gün süreyle balon uçurmak üzere gerekli iznin verildiği bildirilmiştir (BOA, BEO, 266820, 14 Mayıs 1325/27 Mayıs 1909).

Fransız havacilar Delormo ve Barbout, 28 Mayıs 1909 tarihinde hazırlıklarını tamamlayarak Taksim Talimhane Meydanından balon ile havalanmıştır. Osmanlı vatandaşları bir bilet karşılığında bu gösteriyi izlemeye hak kazanmıştır. Balon, İstanbul Boğazı üzerinden hareketle Çamlıca'yı geçip Bulgurlu'da Yalnızselvi mevkiinde yere inmiştir (Tasvir-i Efkâr Gazetesi, 30 Mayıs 1909; Tanin Gazetesi, 29 Mayıs 1909).

Fransız havacılar Delormo ve Barbout'un İstanbul'daki gösterilerini yaptığı aynı dönem içinde, Mahmut Şevket Paşa, yine Fransız havacılardan Baron De Catters ile Louis Bleriot'u hava gösterileri yapmak üzere İstanbul'a davet etmiştir. Bu davet üzerine Kasım 1909 tarihinde Baron De Catters, Voisin marka uçağı ile İstanbul'a gelmiştir. Baron De Catters ilk uçuş denemesinden önce 
Mahmut Şevket Paşa ile görüşmüştür. Bu ziyaret sirasında Baron De Cattres ile yakından ilgilenen Mahmut Şevket Paşa, hava gösterisini izlemek üzere askerî personelden oluşan bir heyet oluşturulmasını istemiştir (Kurter, 2009: s.29). Baron De Catters, gerekli hazırlıklarını tamamladıktan sonra 2 Aralık 1909 tarihinde Hürriyet-i Ebediye Tepesinden havalanmış, ancak kısa bir süre sonra Bulgar Hastanesinin bulunduğu bölgeye zorunlu bir iniş yapmıştır (Tasvir-i Efkâr Gazetesi, 3 Kânunuevvel 1909). Bu uçuş, Türk göklerinde gerçekleştirilmiş olan ilk tayyare uçuşu olarak tarihe geçmiştir (Kline, 2002: s.51). Gösteriyi izlemek üzere yaklaşık iki bin kişi toplanmıştır (Tasviri Efkâr Gazetesi, 3 Kanunuevvel 1909; Kansu vd., 2006: s.115-116). Baron De Catters ikinci hava gösterisini 5 Aralık 1909 tarihinde, yaklaşık on bine yakın bir izleyici kitlesi önünde gerçekleştirmiştir. Ancak, Baron De Catters, Hürriyet-i Ebediye Tepesi üzerinde bir saate yakın süren bir uçuş sonrasında Kâğıthane Deresinin bulunduğu bölgeye zorunlu ve sert bir iniş yapmak zorunda kalmıştır (Tanin Gazetesi, 13 Aralık 1909; Tasvir-i Efkâr Gazetesi, 11, 13, 15 Aralık 1909).

Baron De Catters'ın, başarısız uçuş denemesinden birkaç gün sonra İstanbul'a, Fransız tayyareci Louis Bleriot gelmiştir. Bleriot, 10 Aralık 1909 tarihinde yapacağı hava gösterisi ile ilgili gazetelere ilan vermiş, aynı günün akşamında bir konferans vererek Manş Denizini geçişi ile ilgili bir film gösterimi yapacağını duyurmuştur (Tasvir-i Efkâr Gazetesi, 13 Kanunuevvel 1909). Hava gösterisi öncesinde uçak, Beyoğlu'nda halkın ziyaretine açılmıştır. Louis Bleriot, 11 Aralık 1909 günü Taksim Kışlası'ndaki Talimhane'den askerî ve sivil devlet erkânı ve on bin kişilik halk topluluğu önünde uçağıyla havalanmıştır. Ancak şiddetli rüzgârın etkisiyle uçak, Kurtuluş civarında Marangoz Andon adlı bir Rum vatandaşın evine çarparak düşmüştür (Resimli Kitap Mecmuas1, Kanunuevvel 1325/Aralık 1909; Tasvir-i Efkâr Gazetesi, 13 Kanunuevvel 1909). Bleriot, bu kaza sonrasında el ve bacaklarından yaralanmış, uçağı ise parçalanmıştır. Bu sırada 12 Aralık 1909 günü Sultan Mehmet Reşad ve Mahmut Şevket Paşa, Louis Bleriot'u hastanede ziyaret ederek geçmiş olsun dileklerini iletmiştir (Tanin Gazetesi, 13 Aralık 1909; Tasvir-i Efkâr Gazetesi, 13, 15 Aralık 1909; Resimli Kitap Mecmuası, Aralık 1909). 
Louis Bleriot'un uçuşunu izlemek üzere Harbiye Nezaret-i Kıtaat-1 Fenniye ve Mevak1-i Müstahkeme Müfettişliği Umumiliğinden* gözlem yapmak üzere bir heyet görevlendirilmiştir. Bu heyet Binbaşı İzzet, Kıdemli Yüzbaşı (Kolağası) Hüseyin Hüsnü, Kıdemli Yüzbaşı Cemil ve Kıdemli Yüzbaşı Adil'den oluşmuştur. Bu heyetin 20 Aralık 1909 tarihinde hazırladığı raporda; havacılığın ileride büyük gelişmeler göstereceği, mukavemet gücü yüksek uçakların yapılması ile insanların güvenle havada dolaşabilecekleri, Osmanlı Devletinin bu tip icatları desteklemesi gerektiği, uçakların yakın bir zamanda savaş meydanlarında kullanılmaya başlayacağı belirtilmiştir (Kural, 1975: s.2; Yalçın, 2015: s.231-232). Bu heyetin Louis Bleriot'un uçuşunu izlemek üzere görevlendirilmesi ve bu faaliyetin sonunda havacılık ile ilgili ordu mensuplarınca ayrıntılı teknik tespitlerin yapılıp kapsamlı bir raporun ilk defa hazırlanması, Harbiye Nezaretinin dolayısıyla Osmanlı ordusunun dünyadaki teknik ilerlemeleri ve gelişmeleri çok yakından takip ettiğini göstermektedir. Bu çalışmalar askerî havacılık teşkilatının kuruluşunu somut bir evreye doğru yöneltmiş, kuruluş sürecine bir yön ve istikamet vermiştir.

\section{a. Askerî Havacılık Alanındaki İlk Faaliyetler}

Mahmut Şevket Paşa'nın" 12 Ocak 1910 tarihinde kurulan İbrahim Hakkı Paşa kabinesinde Harbiye Nazırı olarak görev alması Osmanlı ordusunda askerî

\footnotetext{
* Kıtaat-1 Fenniye ve Mevakı-i Müstahkeme Müfettişi Umumiliği: Osmanlı ordusu teşkilatı içerisinde yer alan ve Harbiye Nezaretine bağlı olarak inşaat, emlâk, levazım, istihkâm, mühendislik ve havacılık gibi çok geniş bir alandaki faaliyetlerden sorumlu bir müfettişliktir. Bu müfettişlik tarafından istihkâm işleri, ordu bünyesinde ihtiyaç duyulan gerekli malzemelerin tedariki, satın alma ve sevk, proje çizimi, yapımı, onarımı, balon ve tayyare satın alınması gibi pek çok faaliyet yürütülmüştür. Kıtaat-1 Fenniye ve Mevakı-i Müstahkeme Müfettişi Umumiliği metin içinde bundan sonra Kıtaat-1 Fenniye Müfettişliği olarak yer alacaktır.

* Mahmut Şevket Paşa: 1856 yılında Bağdat’ta doğmuştur. Babası, Kafkasya'dan Irak'a göç etmiş bulunan Basra Mutasarrıfı Kethüdazade Süleyman Faik Bey’dir. 1873-1876 yılları arasında Kuleli Askerî İdadisinde, 1876-1878 yılları arasında Mekteb-i Harbiye'de, 1878 1880 yılları arasında Erkân-1 Harbiye'de eğitim görmüştür. 1880 yılında Erkân-1 Harbiyeden kurmay yüzbaşı olarak mezun olmuştur. 1883 yılında Mekteb-i Harbiye'de yenileşme çalışmaları için Almanya'dan gelen Binbaşı Baron Von der Goltz'un (Mareşal Baron Von der Goltz) muavinliğini yapmıştır. İkinci Meşrutiyetin ilanından sonra 1908 yılında Selanik'te bulunan 3'üncü Ordu Komutanlığı ve Rumeli Müfettişliğgine atanmıştır.
} 
havacılık ile ilgili gelişmelerin hız kazanmasına yol açmıştır. Bu kapsamda Harbiye Nezareti'nin girişimleri ile ilk olarak Ocak 1910 tarihinde Edirne Kalesi'nde kullanılmak üzere sabit balon tedarik edilmesi için çalışmalara başlanmıştır. Bu sırada Avrupa'ya havacılık ve balonculuk konusunda tetkiklerde bulunmak amaciyla gönderilen Miralay Nuri ve Yarbay Galip Bey’e, Berlin Askerî Ataşesi Kurmay Binbaşı Enver Bey ile birlikte Fransa ve Almanya'daki balon fabrikalarını gezerek beğendikleri bir balonu satın almaları yetkisi verilmiştir. $\mathrm{Bu}$ kapsamda, Alman Riedinger firması ile yapılan anlaşma ile biri yedek olmak üzere iki adet Alman Drachen tipi balon alınması ve üç ay içinde Edirne'de teslimatının yapılması konusunda anlaşmaya varılmıştır (Kural, 1975: s.13). Erkân-1 Harbiye Dairesi, balon alımı konusunu takip ederek sonuçlandırması için Kıtaat-1 Fenniye Müfettişliğine göndermiştir. Müfettişlik balon tedarikinin önemini kabul etmekle beraber balon parasının bir önceki yılın mali bütçesinde yer aldığını ve o yıl kullanılmadığı için Maliye Nezaretinden yeni bir tahsis yapılması gereğini, bu nedenle balon alımının ertelenmesi gerektiğini bildirmiştir (BOA, BEO, No: 281907, 23 Cemaziye'l-Evvel 1328/02 Haziran 1910). Neticede seçimi yapılarak sözleşmesi hazırlanan balon tedarik işi, maddi yetersizlikler nedeniyle bir süre daha ertelenmek zorunda kalmıştır (Kural, 1975: s.1-2, 14-15).

Havacılık çalışmalarının giderek arttığı bir dönemde 17-21 Eylül 1910 tarihinde, Fransız ordusu tarafından Picardie bölgesinde büyük bir askerî tatbikat gerçekleştirilmiştir. Bu askerî tatbikata Osmanlı Devleti adına, Paris Askerî Ataşesi Kurmay Kıdemli Yüzbaşı Ali Fethi (Okyar), Üçüncü Ordu Kurmay Başkanı Ali Rıza Paşa, Binbaşı Selâhattin ve Üçüncü Ordu Subay Talimgâhı Komutanlığında

13 Nisan 1909 (Rumi 31 Mart 1325) yılında ortaya çıkan “31 Mart Vakası” üzerine Selânik’ten yola çıkan Hareket Ordusu'nun genel komutanlığını üstlenmiş İstanbul'a gelerek isyanın bastırılmasında etkin rol oynamıştır. 18 Mayıs 1909'da Birinci, İkinci ve Üçüncü Ordular Müfettişliğine getirilmiştir. Mahmut Şevket Paşa, 12 Ocak 1910'da kurulan İbrahim Hakkı Paşa kabinesinde Harbiye Nazırı olmuştur. 23 Ocak 1913'te tarihe "Bab-1 Âli Baskını" olarak geçen olayın sonucu Sadrazam Kâmil Paşa kabinesi istifa etmiş ve yeni kabine Mahmut Şevket Paşa tarafından kurulmuştur. Sadrazam Mahmut Şevket Paşa kabinede, Harbiye Nazırlığı görevini de uhdesine almıştır. 11 Haziran 1913 günü Beyazıt Meydanında, makam otomobilinin içindeyken uğradığı silahlı saldırı sonucu öldürülmüştür. Cenazesi, İstanbul'un Şişli semtinde, 31 Mart Şehitlerinin anısına dikilmiş olan Abide-i Hürriyet Anıtının bulunduğu Hürriyet-i Ebediye Tepesine gömülmüştür (Türkmen, TDV İslam Ansiklopedisi, s.384-386). 
görevli Kurmay Yüzbaşı Mustafa Kemal (Atatürk) Beyler katılım sağlamıştır (Okyar, 1980: s.125-126). O dönemde genç bir kurmay subay olan Mustafa Kemal Atatürk, askerî havacılıkla ilk kez burada tanışmış ve ilk hava harekâtı ile ilgili tecrübelere burada tanıklık etmiştir (Aydar, 1948: s.21). Manevra bitiminde Fransızlar, talep eden gözlemcilerin uçağa binebileceğini belirtmiştir. Bunun üzerine Yüzbaşı Mustafa Kemal, belirtilen bir uçağa binmek için hareketlenmiş, ancak Osmanlı heyet başkanı Ali Rıza Paşa'nın kendisini durdurarak "Bilmediğin aş ya karın ağrıtır ya baş..." şeklinde uyarması üzerine bu talebinden vazgeçmiştir. Bunun üzerine uçağa başka bir gözlemci binmiştir. Bu uçak, uçuş sırasında kırım geçirerek düşmüş ve Yüzbaş1 Mustafa Kemal muhtemel bir ölümden kurtulmuştur (Özkurt, 2017: s.42; Borak, 1965: s.52).

Picardie Manevrası, hava araçları ve kumanda edilebilir balonların ilk defa kullanılması yönüyle ön plana çıkmıştır. Manevrada on dört adet uçağın yanında, dört adet yönetilebilir balon da ilk defa kullanılmıştır. Bu durum, özellikle havacılık tarihinde bir devrim olarak kabul edilmiştir. Özellikle uçakların askerî harekâtta keşif ve gözetleme açısından önemi, bu manevrayla ortaya çıkmış ve birçok ülke, kazandığı bu tecrübe sonucu askerî havacılığa daha çok önem vermeye başlamıştır (Özkurt, 2017: s.42-43).

\section{b. Kurmay Yarbay İsmail Bey Başkanlığında İlk Tayyarecilik Komisyonun Kurulması}

Picardie Manevraları'ndan sonra birçok ülke askerî tayyarecilik teşkilatını kurmaya başlamış ve Fransa'ya askerî pilot yetiştirmek için personel göndermeye başlamıştır. Bütün bu gelişmeler sonucunda Erkân-1 Harbiye Dairesi, havacılığın gelecekte kazanacağı önemi değerlendirerek askerî havacılığın kuruluşu için çalışmalarını hızlandırmıştır. Bu kapsamda, 13 Ekim 1910 tarihinde Kıtaat-1 Fenniye Müfettişliğine gönderilen yazıda; büyük devletler ile komşu hükûmetlerin balon ve tayyarelere verdiği önemin arttığ 1 , bu konuda ilgili devletlerin teşkilatlanma çalışmalarına girdikleri, hava araçları teminine yönelik faaliyetlere başladıkları, Osmanlı Devletinin ilgili devletlerden geri kalmaması için hava araçları teçhizi ve araç temini öncesinde, bu araçları idare edecek personelin yetiştirilmesinin lüzumlu olduğu, bu konuda tahsil etmek üzere ertesi yıl birkaç 
subayın Avrupa'ya gönderilmesi gerektiği belirtilmiştir. Ayrıca, hava araçlarını kullanma konusunda personelde ne gibi özellikler aranması gerektiği, nerelerde hangi maliyetle personel eğitilebileceği gibi hususların ataşelikler aracılığıyla araştırılmasının uygun olacağı ifade edilmiştir (Kural, 1975: s.18-19; Kline, 2002: s.54).

Aynı dönemde, Hariciye Nezaretinden Harbiye Nezaretine 26 Ekim 1910 tarihinde gönderilen yazıda; Bulgaristan'ın Fransa'ya üç adet uçak sipariş ettiği, Yunanistan'ın uçak alımı konusunda araştırmalar yaptığı ve Rusya'nın Fransız Zodiac firmasından bir balon aldığı haberleri iletilmiştir. Bu durum bölge dengelerinde Osmanlı aleyhine olumsuz bir vaziyetin ortaya çıkmasına yol açmıştır. Bu nedenle Osmanlı Devleti, Avrupa'ya tayyarecilik eğitimi alması için personel gönderilmesi ve uçak tedariki çalışmalarını öne almasına etki etmiştir (Kurter, 2009: s.45).

Harbiye Nezareti, 5 Şubat 1911 tarihinde Paris ve Berlin'deki askerî ataşelere gönderdiği yazı ile Almanya ve Fransa'da pilotluk eğitimi konusunun araştırılmasını ve ücretinin bildirilmesini istemiştir. Bu sırada yurtdışında pilotaj eğitimi konusu araştırılırken, Osmanlı Erkân-1 Harbiye Dairesi tarafından 13 Şubat 1911 tarihinde bir genelge yayımlanmıştır. Bu genelgede; aralarından Avrupa'da tayyarecilik eğitimine gönderilecek adayları seçmek üzere her ordudan ikişer subayın belirlenmesi istenmiştir. Bu subayların, salıncak ve denizden başlarının dönmemesi, cesaret ve sebat sahibi olmaları, tabiye bilgilerinin iyi olması aranan nitelikler olarak belirtilmiştir. Ayrıca, tayyarecilik konusunu öğrenmeye hevesli, yabancı dil bilen subayların müracaatta bulunmaları istenmiştir. Erkân-1 Harbiye, ilgili nitelikleri taşıyan teğmen ve yüzbaşı rütbesindeki iki kişiyi sınava tabi tutarak Avrupa'ya pilotaj eğitimine göndermeyi planlamıştır (Genelkurmay Askerî Tarih ve Stratejik Etüt Daire Başkanlığı Arşivi, ATASE, BHK, K: 328, D: 23/2319, F: 27).

Paris Askerî Ataşeliğinin pilotaj eğitimine yönelik yazıya 25 Nisan 1911 tarihinde verdiği cevapta, Fransa Hükümetinin askerî okullardan ziyade sadece sivil hava okullarında kişi başı 800 frank ücret ve 150 frank sigorta karşılı̆̆ pilotaj eğitimi verebileceği bilgisine yer vermiştir. Ayrıca, Paris Askerî Ataşesi Kurmay Binbaşı Ali Fethi (Okyar) Bey; Bleriot, Deperdussin ve R.E.P. tayyarelerinden alınmasını ve on subayın Fransa'da eğitim görmesini önermiştir (ATASE, BHK, K: 
328, D: 23/2319, F: 2-9). Berlin Askerî Ataşeliği ise Almanya'da pilotaj eğitiminin kişi başı 2.500 mark olduğunu bildirmiştir. Ayrıca Almanların, uçak kırım zararının tazminini şart koştuklarını belirtmiştir (ATASE, BHK, K: 328, D: 23/2319, F: 2-8).

Erkân-1 Harbiye Dairesinin 28 Mayıs 1911 tarihli yazısında; tayyarecilik tahsili için Avrupa'ya gönderilmek üzere yedi subayın müracaat ettiği, bunlardan lisan bilenlerin tercih olunacağ olup olmadığının anlaşılması ve motorlarla ilgili bilgilerinin ölçülmesi için müsabaka imtihanlarının kimler tarafından, ne suretle tertip edilmesi lazım geleceğinin tespiti konusunda, Kıtaat-1 Fenniye Müfettişliğinin görevlendirildiği ifade edilmiştir. Ayrıca Erkân-1 Harbiye Dairesi, Avrupa'ya pilotaj eğitimine gönderilecek personelden birinin Fransa'ya, diğerinin ise Almanya'ya öğrenim görmek üzere toplam iki subayın eğitim almasının yeterli olacağını belirtmiştir (ATASE, BHK, K: 328, D: 2319, F: 2-10). İlgili yazıdan Kitaat-1 Fenniye Müfettişliğinin, tayyarecilik faaliyetleri kapsamında Avrupa'ya gönderilecek personelin seçimi, sınavın ne şekilde ve kimler tarafından yapılacağı gibi konularda yetkili kılındığı anlaşılmaktadır.

Yukarıda adı geçen faaliyetlerin icrası ve tayyarecilik faaliyetlerini yürütmek maksadıyla 1 Haziran 1911 tarihinde, Kıtaatı Fenniye Müfettişliğinin önerisi ve Erkânı Harbiye Dairesinin uygun görmesi üzerine bir komisyon kurulması kararlaştırılmıştır (ATASE, BHK, K: 328, D: 2319, F: 2-15). Teşkili kararlaştırılan bu komisyon, Osmanlı Ordusu'nda askerî havacılığın ilk teşkilatı olarak kabul edilmiştir.

Türk askerî havacılığının ilk kuruluşu ile ilgili bugüne kadar yapılan birçok araştırmada yukarıda bahsi geçen komisyonun Kurmay Yarbay Süreyya (İlmen) Bey başkanlığında oluşturulduğu ve 1 Haziran 1911 tarihinde teşkil edildiği görüşü öne sürülmüştür. Bu görüşü ifade eden yayımlar, Kurmay Yarbay Süreyya İlmen tarafindan hazırlanan ve Genelkurmay ATASE Arşivinde yer alan raporlar (ATASE, BHK, K: 179, D: 92, F: 1-08 (9-15), ATASE, BHK, K: 179, D: 92, F: 013, 013-01-02) ile yine Süreyya İlmen'e ait olan “Türkiye'de Tayyarecilik ve Balonculuk Tarihi (İlmen, 1982: s.20)" adlı eseri kaynak olarak göstermişlerdir. Ancak Kurmay Yarbay Süreyya (İlmen) Bey'in raporu ve eserinde, Tayyare Komisyonunun kuruluşu ile ilgili tarih vermemesine rağmen, havacılık tarihi ile 
ilgili yapılan çalışmalarda kendisi başkanlığında oluşturulan Tayyare Komisyonu'nun kuruluş tarihi olarak 1 Haziran 1911 verilmiştir. Konu hakkındaki çalışmanın ilerleyen safhalarında açıklandığı gibi görülecektir ki; Kurmay Yarbay Süreyya (İlmen) Bey başkanlığında kurulan komisyon, Mart 1912 tarihinde teşekkül etmiş olup, Tayyare Mektep ve Merkezinin kuruluşunda etkili olacaktır. Dolayısıyla Türk askerî havacılık tarihinde kurulan ilk komisyon Süreyya Bey başkanlığında değil, Kurmay Yarbay İsmail Bey başkanlığında kurulacaktır.

Askerî havacılık tarihine yönelik arşiv araştırması ve tetkikler sonucunda kuruluş ve teşkilatlanma konusunda çeşitli çalışmalar yapıldığı bugüne kadar tam ve net bilgiler ortaya konmadığı görülmektedir. Bu kapsamda yapılan araştırma sonucunda, tarih metodolojisi ve yorum teknikleri çerçevesinde aşağıdaki çıkarımlara ulaşılmıştır:

Türk askeri havacılığının kuruluşu olarak kabul edilen 1 Haziran 1911 tarihinin 1960 yılında Türk Hava Kuvvetlerinin kuruluş tarihi olarak kabul edildiği görülmektedir (Kurt, 2010: s.50). Ancak, Süreyya (İlmen) Bey'in ATASE Arşivinde yer alan raporu incelendiğinde, bu konuda tam ve net bir tarih vermediği, sadece Yüzbaşı Fesa ile Üsteğmen Yusuf Kenan Beylerin Avrupa'ya pilotaj öğrenimine gönderileceği sırada kendisinin havacılık işleri ile ilgilenmek amacıyla görevlendirildiği bahsi söz konusudur. Süreyya Bey'in ilgili beyanı esas alınarak, kendisi başkanlığında oluşturulan komisyon zorlama bir yorumla sanki 1 Haziran 1911 tarihinde teşkil edilmiş gibi aktarılmıştır. Bir yorum hatasından kaynaklı bu durumun daha sonra yapılan birçok inceleme, araştırma ve akademik esere konu olduğu, ancak konunun tarihi bir süzgeçten geçirilmeden doğrudan çeşitli eserlere aktırıldığı görülmektedir. Yapılan arşiv araştırması ile Kurmay Yarbay Süreyya (İlmen) Bey'in başkanlığında oluşturulan tayyarecilik komisyonunun Mart 1912'de tayyare mektep ve merkezinin kurulması için oluşturulduğu tespit edilmiştir. Makalenin ilerleyen aşamalarında konu arşiv belgeleri ışığında ortaya konulmuştur.

Hava Kuvvetlerinin kuruluşu olarak kabul edilen ilk Tayyare Komisyonunun Kurmay Yarbay Süreyya (İlmen) tarafından teşkil edilmediği, havacılık ile ilgili ilk komisyonun (19 Mayıs 1327) 1 Haziran 1911 tarihinde alınan 
kararla birlikte, Erkan-1 Harbiye-i Umumiye Dairesi* 2'nci Şubesinde görevli Kurmay Yarbay İsmail Bey başkanlığında kurulduğu değerlendirilmektedir. Bu tezi destekleyen önemli doküman ve arşiv belgeleri olduğu yapılan araştırma sonucu görülmüştür. Şöyle ki ATASE Arşivinde yapılan incelemede; 1 Haziran 1911 tarihinde tayyarecilik faaliyetleri ve Avrupa'ya pilotaj eğitimine gönderilecek personelin motorlara derece-i vukuflarını ve lisan bilgilerini anlamak üzere bir komisyon teşkiline karar verildiği tespit edilmiştir (ATASE, BHK, K: 328, D: 2319, F: 2-15). İlgili belgede ifade edilen tayyare komisyonunun kuruluş kararı ile Türk Hava Kuvvetlerinin temelleri atılmıştır. Komisyonun Kurmay Yarbay İsmail Bey başkanlığında tesis edildiğini gösteren en önemli argüman, Avrupa'ya gönderilecek aday personelin seçimi ile tayyareciliğe yeteneklerinin anlaşılması ve lisan durumlarının tespitine yönelik yapılan sınav sonuçlarını içeren 29 Haziran 1911 tarihli belgedir (ATASE, BHK, K: 328, D: 2319, F: 2-22). Illgili belgede, yapılan sınava dair sonuçlara yer verilmiştir. Ayrıca aynı belgede Türk askerî havacılığının kuruluşuna dair Kurmay Yarbay İsmail Bey başkanlığındaki tayyarecilik komisyonun üyelerinin isimlerine de yer verilmiştir. Kurmay Yarbay İsmail Bey Başkanlığında oluşturulan havacılığa dair bu ilk komisyonda; Kıtaatı Fenniye Şubesi Azasından Binbaşı Ali, Kıtaatı Fenniye Müfettişliği Projektör Müfettişi Binbaşı Ali Rıza, Elektrik ve Projektör Öğretmeni Mehmed Şevki ve Elektrik ve Projektör Öğretmeni Vekili İbrahim Fahri Beyler yer almıştır. Dolayısıyla Osmanlı Ordusunda havacılık faaliyetleri ile ilgili ilk komisyon yukarıda adı geçen kişilerden meydana gelmiştir.

\footnotetext{
* Erkânı Harbiye-i Umumiye Dairesi: 1848 yılında Erkânı Harbiye Mektebinin (Harp Akademisi) kurulması ve kurmay subayların ordu içinde görev almaya başlaması ile birlikte kurmay subayların eğitim-öğretim, görevlendirme ve karargâhta kurmaylık hizmetlerini yürütmek amacıyla 1860 yılında Bâbı Seraskerî’nin içinde Erkânı Harbiye Şubesi olarak kurulmuştur. 1880 yllında yedi şubeli bir daire hâline getirilen Erkân-1 Harbiye Dairesi, 1881 yılında "Erkânı Harbiyei Umumiye Dairesi adını almıştır. İkinci Meşrutiyetin (23 Temmuz 1908) ilanından sonra yapılan düzenlemeyle Bâb-1 Seraskerî makamı, Harbiye Nazırlığı adını alarak Osmanlı Devleti'nin yıkılışına kadar varlığını sürdürmüştür. 15 Ağustos 1908'de Erkânı Harbiyei Umumiye Dairesi, Harbiye Nazırlığına bağlı bir daire olarak varlığını devam ettirmiştir. Erkân-ı Harbiyei Umumiye Dairesi, metin içerisinde bundan sonra Erkânı Harbiye Dairesi olarak yer alacaktır (İskora, 1944).
} 
İlk tayyare komisyonu başkanı Kurmay Yarbay İsmail Bey, tayyarecilik eğitimi için Avrupa'ya gönderilecek personelin belirlenmesi sürecinde, havacılık faaliyetlerinin en başından itibaren içerisinde yer almıştır. Bu durumu kanıtlayan en önemli belge 13 Şubat 1911 tarihli emirdir (ATASE, BHK, K: 328, D: 2319, F: 2-7). Erkân-1 Harbiye Dairesi 2'nci Şubesi tarafindan 1, 2 ve 3'üncü Ordulara yayımlanan bu emirde, Kurmay Yarbay İsmail Bey'in adı ile imzası bulunduğu görülmektedir (ATASE, BHK, K: 328, D: 2319, F: 2-23). 13 Şubat 1911 tarihinde yayımlanan emir, Osmanlı Ordusunun Avrupa'ya pilotaj eğitimine personel gönderileceğini ilan ettiği ilk belgedir.

Askerî havacılık teşkilatının kuruluşuna dair ayrıntılı bilgi ve açıklamalar ilerleyen sayfalarda derinlemesine aktarılacak ve konu hakkındaki değerlendirmeler yapılan çıkarım ve analizlerle ifade edilecektir. Havacılıkla ilgili çalışmaların anlaşılması açısından yukarıda yapılan değerlendirmelerle tarihi kronolojinin dışına çıkılmış ve konu netleştirilmeye çalışılmıştır. Konunun anlaşılması için tayyarecilik çalışmalarına yönelik adımlar, arşiv belgeleri ışı̆̆ında kronik bir sıraya göre işlenmeye devam edecektir.

Askerî havacılık teşkilatının ilk temelini oluşturan 1 Haziran 1911 tarihli tayyare komisyonunun kurulmasına yönelik karar sonrasında, Erkânı Harbiye Dairesi İkinci Şubesi tarafından 3, 6 ve 20 Haziran 1911 tarihlerinde Birinci, İkinci ve Beşinci Kolordu Komutanlıklarına gönderilen yazılardan pilotaj eğitimine gönderilecek aday personelin, 28 Haziran 1911 tarihinde yapılacak olan sinavlara gelmelerinin istendiği görülmektedir (ATASE, BHK, K: 328, D: 2319, F: 2-11.; ATASE, BHK, K: 328, D: 2319, F: 2-13).

Avrupa'ya pilotaj eğitimine gönderilecek adaylar ile ilgili Erkânı Harbiye Dairesi tarafından 13 Şubat 1911 tarihinde yayımlanan genelgeden yaklaşık dört ay sonra sınav gerçekleştirilmiştir. Bu sınavda, 92 puan alan Süvari Yüzbaşı Mehmet Fesa (Evrensev) ile 91 puan alan İstihkâm Üsteğmen Yusuf Kenan Beyler Avrupa'da eğitim almaya hak kazanmıştır (ATASE, BHK, K: 328, D: 2319, F: 222). Üsteğmen Yusuf Kenan Bey'in 22 Haziran 1911'de, Yüzbaşı Fesa Bey'in ise 3 Temmuz 1911 tarihinde yapılan sağlı muayenelerinde tayyarecilik tahsillerine herhangi bir engel bulunmadığ 1 tespit edilmiştir (ATASE, BHK, K: 328, D: 2319, F: 2-19.; ATASE, BHK, K: 328, D: 2319, F: 2-23). Sağlık raporlarının alınması sonrasında, daha önce Almanya'ya da personel gönderilmesi kararına rağmen, 
Fransa'da uçak teknolojisinin diğer ülkelerden ileride olması ve eğitim maliyetinin daha düşük olması gibi nedenlerle, her iki aday da 9 Temmuz 1911 tarihinde Fransa'ya Bleriot Tayyare Fabrikasının Uçuş Okuluna gönderilmiştir (Kapucu, 2015: s.6.; İlmen, 1947: s.9). Bu sırada, 4 Temmuz 1911 tarihli yazı ile Teğmen Hikmet Bey'in kendi nam ve hesabına Fransa'da pilotaj eğitimine başladığı belirtilmiştir. Ancak, Teğmen Hikmet Bey'in sonradan öğrenimden vazgeçtiği anlaşılmaktadır (Kural, 1975: s.28-29).

\section{c. Tayyare Mektep ve Merkezi'nin Kurulması Aşamasında Kurmay Yarbay Süreyya (İlmen) Bey'in Faaliyetleri}

Türk Hava Kuvvetleri tarihinde oluşturulan İlk komisyonun, Kurmay Yarbay İsmail Bey başkanlığında Avrupa'ya gönderilecek personelin seçim faaliyetlerini gerçekleştirmesinden sonra, Osmanlı Devletinin ekonomik sıkıntıları nedeniyle personelin İstanbul'da açılacak bir merkezde yetiştirilebileceği değerlendirilmiştir. Bu kapsamda İstanbul'da bir tayyare mektep ve merkezi açılması için bir komisyon kurulması gündeme gelmiştir. Bu süreç Kurmay Yarbay Süreyya (İlmen) Bey başkanlığında yeni bir komisyonun teşkiline zemin hazırlamıştır. İlgili başlık altında havacılık tarihindeki bu ikinci komisyonun kuruluş süreci ve faaliyetleri ortaya konacaktır. Ayrıca bu başlık altında, tayyare mektep ve merkezinin açılış süreci, bu süreci etkileyen iç ve dış gelişmeler ile ekonomik, siyasi ve bürokratik etkenler çok yönlü olarak işlenecektir.

Uçak alımı ile ilgili Erkân-1 Harbiye 2'nci Şubesi tarafından Kıtaat-1 Fenniye Müfettişliğine 15 Ağustos 1911'de gönderilen muhtırada; Paris’te tayyarecilik öğrenimi gören üç subayın bir aya kadar eğitimlerini tamamlayacakları, pilotların kazandıkları becerilerini kaybetmemeleri için vakit kaybetmeden iki uçak satın alınması gerektiği ifade edilmiştir. Ayrıca Müfettişliğin satın alınacak uçakları konuşlandırmak üzere yer bulması ve tahsisat çıkarmak üzere girişimde bulunması ve bu konuda kendisinin yetkili kılındığı bildirilmiştir (Kurter, 2009: s.49.; Kural, 1975: s.29). İlave olarak, Fransa'da eğitim gören tayyareci subayların yakında yurda dönecek olmaları nedeniyle şimdiden iki tayyarenin satın alınması için bütçeden bir meblağın verilmesine müsaade edilmesi istenmiş̧tir. Aynı yazıda tayyareler için özel bir yer tespiti maksadıyla Kıtaat-1 
Fenniye Müfettişliğine gerekli emrin verilmesinin önemli olduğu ifade edilmiştir (Kural, 1975: s.29-31).

Uçak satın alma girişimlerinin başlatıldığı, Avrupa'ya pilotaj öğrenimi için personel gönderildiği bir dönemde, İtalya'nın saldırısı ile 29 Eylül 1911 tarihinde Trablusgarp Savaşı başlamıştır (Ertan, 2012: s.58-59). Bu savaşta dünya tarihinde ilk kez uçaklar, savaş aracı olarak kullanılmaya başlanmıştır. Böylece, uçağın muharebe sahasında kullanılmasının yarattığı etkiler, Osmanlı Harbiye Nezareti tarafından bizzat tecrübe edilerek değerlendirilmiştir. Neticede bu süreç, uçak alımı ve bunların muhafazası için yer konularının daha yoğun bir şekilde gündeme gelmesine yol açmıştır (Kline, 2002: s.56-58).

Osmanl1 ordusuna mensup Fesa ve Yusuf Kenan Beylerin Fransa'da eğitime başladığı sırada, iki adet uçağın tedarik edilmesi kesinlik kazanmıştır. Erkân-1 Harbiye Dairesi, Kıtaat-1 Fenniye Müfettişliğine 7 Ekim 1911 tarihinde gönderdiği yazı ile uçak satın alma işlemlerinin başlatılması için Paris Sefareti ile iletişim kurulmasını istemiştir. Bu kapsamda başlatılan işlemler sonucunda Paris Sefaretine uçak alımı konusu resmî olarak bildirilmiştir. Bu sırada Paris Askerî Ataşe Vekili Yüzbaşı Süleyman Tevfik Bey’in girişimleri ile uçak satın alma işlemleri yürütülmüştür. Neticede Yüzbaşı Süleyman Tevfik Bey'in faaliyetleri sonucunda Deperdussin model iki adet uçak satın alınmıştır (Kurter, 2009: s.74).

Paris Askerî Ataşe Vekili Yüzbaşı Süleyman Tevfik Bey, 29 Aralık 1911 tarihinde Harbiye Nezaretine gönderdiği yazıda, İstanbul'da tesisi düşünülen tayyare mektebi hakkında araştırma yaptığını, mektebe ilişkin raporla, mektep teşkilatına yönelik önemli birkaç projeyi göndereceğini bildirmiştir (ATASE, BHK, K: 3, D: 7/13, F: 19-1). Aynı gün, REP Tayyare Mektebi Müdürü Hugues Simon tarafindan Türkiye'de bir tayyare mektebi ve havacılık merkezi kurmaya yönelik projesi, İstanbul'a gönderilmek üzere Paris Sefareti'ne iletilmiştir (BOA, HR.SFR.(3).656.001.003). Bu projede, askerî havacılık alanındaki eğitimin Türkiye'de yapılmasının uygun olacağı belirtilmiş̧ir (BOA, HR.SFR.(3).656.001.00). Mösyö Simon'un projesini içeren müracaatı 2 Ocak 1912 tarihinde Harbiye Nezaretine gönderilmiştir (BOA, HR.SFR.(3). 00656. 00001. 001).

Yine aynı kapsamda, Erkânı Harbiye Dairesi tarafından 13 Ocak 1912 tarihinde Kıtaat-1 Fenniye Müfettişliğine gönderilen yazıda; İstanbul'da bir tayyare 
mektebi inşası için iki tayyare satın alınacağı, bir tayyareci ile bir makinist temini konusunda anlaşma yapıldığı ve Paris’te eğitim gören subayların yakın bir zamanda dönecekleri belirtilmiştir. İlaveten, tayyare mektebinde görev yapması planlanan öğretmenle üç ay müddetle bir kontrat yapıldığı, öğretmen İstanbul'a geldiği zaman, teşkilat ve inşaata yönelik hazırlıkların şimdiden yapılmaya başlanması gerektiği bildirilmiştir. Bu bağlamda, Kıtaatı Fenniye ile Erkânı Harbiyeden tayin edilecek iki mühendis subay ve bu subaylardan oluşan bir komisyon teşkil edilerek, tayyare mektebi için İstanbul civarında muhtelif rüzgâr cereyanlarından korunan, bir kilometre uzunluğunda ve yarım kilometre eninde uygun bir meydan yeri seçileceği belirtilmiştir. Aynı yazıda kolordulardan tayyarecilik mektebine subay ve astsubay gönderilerek talim ve terbiye edilecekleri, tayyare sınıfı Kıtaatı Fenniye Müfettişliğine bağlı bulunduğundan, tayyare müfrezesi ve tayyare mektebi kadrolarının tespiti, teşkilat ve inşaata yönelik masrafların icrası gibi konularda bu muhtıranın Müfettişliğe gönderildiği ifade edilmiştir (ATASE, BHK, K: 31, D: 2/42, F: 47.; ATASE, BHK, K: 142, D: 31-2, F: 47).

Tayyare Mektep ve Merkezinin kuruluşuna yönelik yukarıda bahsi geçen kurulun, Kurmay Yarbay Süreyya (İlmen) Bey başkanlığında oluşturulan komisyonun oluşumuna zemin hazırladığı değerlendirilmektedir. İlgili yazının gündeme geldiği bir dönemde Süreyya Bey'in havacılık faaliyetleri kapsamında görevlendirildiği öngörülmektedir. Dolayısıyla Kurmay Yarbay Süreyya (İlmen) Bey'in başkanlığında kurulan komisyon ile daha önce Kurmay Yarbay İsmail Bey başkanlığında oluşturulan ilk komisyonun birbirine karıştırılmaması gerektiği değerlendirilmektedir.

Bu sırada Fransa'daki Deperdussin Fabrikası, satın alınan iki uçağı 1912 yılı başlarında teslime hazır hâle getirmiştir. Kıtaat-1 Fenniye Müfettişliği, 16 Ocak 1912 tarihinde Paris Sefaretine bir yazı göndererek uçakların Selanik yolu ile İstanbul'a sevk edilmesini istemiştir. Satın alınan uçakların İstanbul'a gelmesi için yazışmalar yapıldığı bir sırada, Osmanlı ordusunda görev yapan beş subayın daha pilotluk eğitimi için Fransa'ya gönderilmesi kararlaştırılmıştır. Bunun üzerine kolordulara gönderilen bir yazı ile fizik olarak kuvvetli ve Fransızca bilen subaylardan istekli olanların pilotaj eğitimine ayrılması istenmiştir (Kurter, 2009: s.76.; Kural, 1975: s.159). 
Londra Büyükelçisi Ahmet Tevfik Paşa tarafindan 19 Ocak 1912 tarihinde Harbiye Nezaretine gönderilen yazıda, Fransız tayyarecilerinden Mösyö Simon'un tayyare mektebi projesi ile ilgili olarak Harbiye Nezareti ile doğrudan doğruya görüşmeler yapmak üzere İstanbul'a gitmeyi kararlaştırdığı, konu hakkında kendisine yardım ve kolaylık gösterilmesi için bir tavsiyename yazıldığ 1 bildirilmiştir (BOA, HR.SFR.(3).00656.00001.007).

Harbiye Nazırı Mahmut Şevket Paşa, 17 Şubat 1912 tarihinde Sadaret'e gönderdiği yazısında; uçakların askerî öneminin hâlihazırda devam eden Trablusgarp Savaşında kendini gösterdiğini, Balkan devletlerinden gerek Bulgaristan ve gerekse Yunanistan'ın ordularında havacıllk okulu ve teşkilatı kurma çabası içerisinde bulunduğunu belirterek Osmanlı ordusunda da bir havacılık okulu kurulmasının önemini ifade etmiştir. Ancak, böyle bir merkez ve mektep için 15.000 lira, alınacak 15 uçak için 20.000 lira ve diğer giderler için de senelik 5.000 lira gerektiğini belirtmiştir. Ayrıca, Harbiye Nezaretinin bütçesinde bu iş için ayrılacak parasının bulunmadığını, bu işin aciliyetinden dolayı 40.000 lira tahsis edilmesinin gerektiğini Sadaret Makamına bildirmiştir (ATASE, BHK, K: 179, D: 92, F: 1.; ATASE, BHK, K: 179, D: 92, F: 1-1., BOA, BEO, 4013.300907.002). Bu teklif Sadaret Makamı tarafından 20 Şubat 1912 tarihinde Maliye Nezaretine gönderilerek, ne güncel ne de olağanüstü bütçede projenin bir karşılığ1 olmadığından, konunun tetkik edilerek acilen bildirilmesi istenmiştir (BOA, BEO, 4005.300301.001.; ATASE, BHK, K: 179, D: 92, F: 001-02). Maliye Nezareti tarafindan Sadaret Makamına 20 Şubat 1912 tarihinde verilen cevapta; yeni icatlardan olan tayyarenin Osmanlı ordusunda bulundurulmasının kaçınılmaz olduğu, ancak bu uğurda 40-50 bin lira sarf olunarak bir mektep açmaktansa, tayyarelerin Avrupa'dan satın alınması ve onları idare edecek subayların Avrupa'da eğitim görmelerinin Osmanlı hazinesinin şuan ki durumuna daha uygun olduğu bildirilmiştir (BOA, BEO, 004017.901212.003).

1912 Şubat ayı içinde Paris Askerî Ataşe Vekili Süleyman Tevfik Bey, Fransa'daki Bleriot Fabrikasının kendisine ait özel Uçuş Okulunda pilotaj eğitimi gören subaylardan Yüzbaşı Fesa (Evrensev) Bey'in, 21 Şubat 1912 tarihinde eğitimi bitirerek diplomasını aldığını bildirmiştir (Kural, 1975: s.209). Fesa Bey, Fransa Hava Kulübünün (Aero Club de France) verdiği 780 numaralı uluslararası brövesinin sahibi olmuş ve "ilk Türk pilotu" unvanını almıştır. Ayrıca, Askerî 
Ataşe Vekili yazısında, yeni pilot adaylarının İngiltere'deki Bristol Uçak Fabrikası'nın Uçuş Okuluna gönderilmesini önermiş ve okulun bir yönetmeliğini de incelenmek üzere göndermiştir. Fabrikanın ortaklarından Mr.Dickson ile yapılan görüşmeler sonucu gönderilecek personele, İngiliz subayı gibi davranılması garantisini aldığını belirtmiştir. Bu koşulun kabul edilmesi sonrasında İngiliz Bristol Fabrikasına iki adet iki kişilik ve tek satıhlı askerî uçak siparişi verilmiştir (Kurter, 2009: s.77.; Kural, 1975: s.209).

Bu sırada 5 Mart 1912 tarihinde Erkânı Harbiye İkinci Şubesinden, Kıtaat-1 Fenniye Müfettişliğine gönderilen yazıda; yapılan araştırma ve incelemeler sonucu hazırlanan muhtıralardan, İstanbul' da inşa edilecek tayyare mektebinde, senede 30 40 tayyareci subayın 15.000 liraya yetiştirilebileceği ifade edilmiştir. Tayyare mektebinde görev yapacak öğretmen ve makinistlere ise tahminî olarak toplam 5.000 lira maaş ödenebileceği belirtilmiştir. Bu hesaplamalara göre, açılacak okulun bir yıllık giderinin 20.000 lira civarında olacağı öngörülmüştür. Ayrıca, öğrenim için başlangıçta 15-20 uçak lazım geleceğinden, bunların toplam bedeli olarak da 20.000 liraya daha ihtiyaç olduğu aktarılmıştır. Böylece, toplam 40.000 liranın okul için sarf edilmesi gerektiği belirtilerek konunun Erkân-1 Harbiye Dairesi tarafından 14 Şubat 1912 tarihinde Harbiye Nezaretine gönderildiği ve onay istendiği belirtilmiştir. Aynı yazıda, Paris Askerî Ataşe Vekili tarafindan, İstanbul'da İmalatı Harbiye Müdürlüğüne bağlı bir uçak fabrikasının 5.000 liraya kurulmasının mümkün olduğunun bildirdiği ve konunun Kitaat-1 Fenniye Müfettişliği tarafindan incelenmesinin uygun olacağı dile getirilmiştir. Yazıda tayyare mektebinin kurulabilmesi için öncelikle bir öğretmen ve bir makinistin getirilmesi gerektiği, bu kapsamda Paris'te mektep kurulmasına yönelik başvuruda bulunan J. Şişmanoğlu adlı şahsın Kıtaat-1 Fenniye Müfettişliği tarafından getirilmesinin münasip olduğu belirtilmiştir. Ayrıca, mektep projesi için yer tespit etmek amaciyla bir komisyon teşkil edilmesi önerilmiştir (ATASE, BHK, K: 328, D: 2319, F: 2-42). Bu komisyonda, mektepte görevlendirilecek öğretmen pilotun, Fransa'dan eğitimden dönecek Yüzbaşı Fesa ile Üsteğmen Yusuf Kenan Beylerin, Erkân-1 Harbiye Dairesinden bir personel ile Kitaat-1 Fenniye Müfettişliğinden dâhil edilecek iki kişinin bulunması gerektiği ifade edilmiştir. Bu komisyonun öncelikle okul için İstanbul civarı, burada bulunamadığı takdirde Muratlı, Çorlu veya Edirne taraflarında yer tespiti için çalışacağı aktarılmıştır. Mektep yerinin 
tespiti sonrasında, mektep için lazım gelen alet ve edevatın Fransa'ya sipariş edilmesi, ardından da projenin hazırlanarak inşasına başlanmasının uygun olduğu vurgulanmıştır (ATASE, BHK; K: 328, D: 2319, F: 2-43).

Aynı yazının devamında, Fransa'dan dönecek olan Fesa ve Yusuf Kenan Beylerin eğitimlerine devam etmeleri ve melekelerinin artması için iki uçağın tedariki ve yurt dışına gönderilecek altı pilot adayı subayın durumlarına da değinilmiştir. Uçak fabrikalarının kendilerinden uçak alındığı takdirde, adaylara ücretsiz öğrenim göstereceklerini bildirmelerine rağmen pilot adaylarının kırım masrafları yüzünden pilotaj eğitiminin pahalı geldiği belirtilmiştir. Bu yüzden pilot adaylarının, Paris Askerî Ataşe Vekili tarafından önerilen İngiltere'deki Bristol Uçak Fabrikası Uçuş Okulu'na gönderilmelerinin daha uygun olduğu ifade edilmiştir. Avrupa'ya gönderilecek pilot adayı subayların seçilmesinde, cesaretleri ile sporla iştigal olup olmadıklarının dikkate alınması gerektiği belirtilmiştir. İki uçak satın alınması ve Fransa'ya eğitime altı subay gönderilmesi konusunda Kıtaat1 Fenniye Müfettişliği tarafından gerekli paranın tedarik edilemediğine yönelik beyanı da yazıya eklenmiştir (ATASE, BHK, K: 328, D: 2319, F: 2-43a). Bunlara ek olarak, büyük devletlerin ve komşu ülkelerin tayyareciliğe büyük önem verdikleri, Osmanlı ordusunda bulunan diğer sınıflar gibi tayyareciliğin de tesis ve teşkili lüzumlu olduğundan, evvelce Harbiye Nezaretinin onayına yollanan 40.000 liranın Kıtaat-1 Fenniye Müfettişliği tarafından takip edilmesi gerektiği belirtilmiştir. Pilot adayı subayların bir an önce eğitime gönderilmesi, okulun kurulması ve tedarik işlemlerinin ivedilikle tamamlanması konusunda Kıtaat-1 Fenniye Müfettişliğine ilgili muhtıranın gönderildiği ifade edilmiştir (ATASE, BHK, K: 328, D: 2319, F: 2-42).

Yukarıda bahsi geçen yazı, bizzat Süreyya Bey'in imzası ile 5 Mart 1912 tarihinde Erkânı Harbiye Dairesinden Kıtaatı Fenniye Müfettişliğine gönderilmiştir. Bu yazıda Tayyare Mektebi'nin yer seçimi konusunda bir komisyon teşkiline gerek olduğu belirtilmektedir. Bu durum Süreyya Bey Komisyonunun Mart 1912'de teşkil edildiğini gösteren önemli kanttlardan biridir.

7 Mart 1912 tarihinde Maliye Nezareti, tayyare mektebi projesi ile ilgili bütçe tahsisi konusunda Sadaret makamına bir yazı daha yazmıştır. Bu yazıda; bütün Avrupa ordularında uçakların gösterdikleri gelişmenin yakından takip edildiği, her türlü fedakârlık gösterilerek Osmanlı ordusunun yenilenip 
geliştirilmesinin gerekli olduğu, bu sebepten, birkaç uçak ile bir mektep açılmasına teşebbüs edildiği belirtilmiştir. Ayrıca, Fransa'nın Deperdussin Fabrikası'na iki tayyare siparişi verilmiş olduğu, ilave olarak iki adet daha sipariş verilmesi için çalışmaların devam ettiği bildirilmiştir. Ancak, üç senelik olağanüstü bütçede; gerek satın alınan, gerekse satın alınacak tayyareler için verilecek olan meblağın karşılığı olmadığından dolayı, önceden harcanan paranın dahi yerine konulamadığ ifade edilmiştir. İlaveten, bina adedinin çoğaltılması ve tayyare mektebi tesisi için ihtiyaç olan meblağ temin edilemediğinden, konunun araştırma inceleme aşamasından ileri gidilemediği beyan edilmiştir.

Yazının devamında, tayyarecilik tahsili için büyük fedakârlık yapılarak Fransa'ya iki subay gönderildiği, arkasından altı subay daha gönderilip, iki adette tayyare alınmasına rağmen paranın ödenememesinden dolayı müşkülat yaşandığ 1 belirtilmiştir. Yapılan masrafların boşa gitmemesi için hiç olmazsa, öğretmenle makinistlerin getirilmesi ve iki tayyarenin alınmasının önem arz ettiği ifade edilmiştir. Bu gelişmelerden dolayı Erkânı Harbiye Dairesi tarafından tayyare mektebi tesisi için istenen 40.000 liranın, Harbiye Nezaretinin ne güncel ne de olağanüstü bütçesinde karşılığı olmadığından, nereden ve ne şekilde temin edileceği hususunun Sadaret Makamı tarafından değerlendirilmesi istenmiştir (BOA, BEO, 004013.300924.002., ATASE, BHK, K: 179, D: 92, F: 001-03., ATASE, BHK, K: 179, D: 92, F: 001-04). Sadaret Makamı tarafindan 9 Mart 1912 tarihli yazıda konunun Hükümet tarafından etraflıca değerlendirilerek karara varılacağ1 belirtilerek, Harbiye Nezaretine incelenmesi amacıyla gönderilmiştir (BOA, BEO, 4013.300907.001., BOA, BEO, 004013.300924.003., ATASE, BHK, K: 179, D: 92, F: 001-05, ATASE, BHK, K: 179, D: 92, F: 001-06).

Sadaret Makamindan 10 Mart 1912 tarihinde Harbiye Nezaretine gönderilen yazıda, Maliye Nezareti ile yapılan görüşme ve yazışmalar sonucunda tayyare mektebi açmaktansa, pilot adayı subayların Avrupa'da eğitilmesinin şu an için hazineye daha uygun olacağı belirtilmiş ve konunun ne kadara mâl olacağının yeniden hesap edilerek bildirilmesi istenmiştir (ATASE, BHK, K: 179, D: 92, F: 001-07.; BOA, BEO, 4013.300914.001). Bu sırada aynı tarihte, Üsteğmen Yusuf Kenan Bey, Fransız Hava Kulübünün 797 numaralı uluslararası brövesini alarak öğrenimini tamamlamıştır (Filo Tarihçeleri, 2009: s.11). 
Maliye Nezaretinin tayyare mektebi kurulması konusundaki beyan1, Osmanlı hazinesinin durumunun ne kadar kötü olduğunu göstermektedir. İleriye dönük hazırlanan ve gelecek üç yılı da bağlayan Osmanlı olağanüstü bütçesinin vaziyeti yazıda dile getirilmiştir. Konu çok boyutlu olarak değerlendirildiğinde, Harbiye Nezaretinin bu stratejik aracı elde etmek için 1srarla girişimlerde bulunduğu anlaşılmaktadır. 1909 yılından itibaren yapılan yazışmalar, Berlin ve Paris Sefaretlerinden talep edilen bilgi ve dokümanlar, bunun en önemli kanıtıdır. Trablusgarp Savaşının devam etmesi ve komşu ülkelerin uçak alımına yönelik faaliyetleri, uçak alımı ve bir tayyare merkezi kurulmasını zorunlu kılmıştır. Ayrıca, Osmanlı ordusu bünyesinde tayyare mektebi açılması ile birlikte personelin eğitimi, uçakların tamirat işlemleri ve bu alandaki önemli bir tecrübenin orduya kazandırılmasına imkân verecektir. Böylece muhtemel bir harpte stratejik bir araç elde edilerek ordu, kendi personel ve harp araçlarını kullanma imkân ve kabiliyetine sahip olabilecektir. Harbiye Nezaretinin konu hakkındaki 1srarlı taleplerine rağmen, ülkenin içinde bulunduğu ekonomik koşullar ve mali çıkmaz, konunun Sadaret Makamı tarafından karara bağlanmasını gündeme getirmiştir.

Harbiye Nezareti tarafindan 12 Mart 1912 tarihinde Sadaret Makamina gönderilen yazı ile tayyare mektebi kuruluşu konusundaki görüş ve düşünceler tekrar beyan edilmiştir. Bu yazıda; Bulgaristan, Sırbistan ve Yunanistan'ın tayyareler satın almaya çalıştıkları, Avrupa'ya tayyarecilik eğitimi için subay gönderdikleri ve tayyare mektepleri açmaya çalıştıkları belirtilmiştir. Ayrıca, piyade, süvari ve topçu sınıflarına ilave olarak eklenen bu dördüncü sınıftan ordunun mahrum kalmasının katiyen kabul edilemeyeceği ifade edilmiştir. Ülkenin içinde bulunduğu harp durumları göz önüne alınarak bir tayyareci sınıfının tesisi için gayret edildiği, şu an için hazinede görüşülen bu konunun dikkatlerden uzak tutulmaması ve son derece önem arz eden bu konudan istifade için çareler araştırılması gerektiği belirtilmiştir. Aynı yazıda, Osmanlı ordusuna tayyarelerin temin edilmesi için şart olan teşkilatın kurulması ile tayyare mektebinin açılması için lazım olan 40.000 liranın tahsisi konusunda bir an evvel gereğinin yapılarak müsaade edilmesi istenmiştir (BOA, BEO, 004017.301212.002). Söz konusu yazı Harbiye Nezaretinin, önemine binaen tayyare mektebi ve bir tayyare merkezi açılması yönünde talebinin ısrarla devam ettiğini göstermektedir. 
Tayyare Mektebinin açılması konusunda devlet kurumları arasında yapılan yazışmaların sonucunda, 17 Mart 1912 tarihli Heyet-i Vükelâ Toplantısında; tayyarecilik konusunda personel Avrupa'ya gönderilerek eğitim aldırılsa bile evvela bir genel merkeze ihtiyaç olduğu, bu merkezde mükemmel bir tayyare parkı, imalathane, tamirhane ve ihtiyaç olan diğer binaların yanı sıra bir mektebin de açılması gerektiği belirtilmiştir. Neticede, böyle bir merkez ve mektep tesisi için Harbiye Nezaretine kırk bin liranın tahsis edilmesi kararlaştırılmışıı (BOA.M.V.001162.00083.001). Böylece, Harbiye Nezaretinin ve özellikle Harbiye Nazırı Mahmut Şevket Paşa'nın uzun uğraşları ve çabaları sonucunda Heyeti Vükelâ tarafından tayyare mektebi ve havacılık merkezinin açılması onaylanmıştır. Bu karar, Sadaret makamı tarafindan 18 Mart 1912 tarihinde Maliye Nezaretine bildirilmiş ve gerekli tahsisatın yapılması istenmiştir (BOA, BEO.004017.301212.001). Böylece uzun uğraşlar sonucunda tayyare mektebi ile bir havacılık merkezinin açılması karara bağlanmış, böylece Osmanlı ordusunun modern ordular ile eş zamanlı olarak askerî havacılık teşkilatlanmasına imkân sağlanmıştır.

Heyeti Vükela kararından sonra tayyare mektep ve merkezinin açılması için bir komisyon teşkil edildiği görülmektedir. Havacıllk tarihindeki bu ikinci komisyonun Kurmay Yarbay Süreyya (İlmen) Bey, başkanlığında oluşturularak faaliyet gösterdiği yapılan arşiv araştırmasında görülmektedir. İlgili sürecin anlaşılmasını kolaylaştıran en önemli kanıt, bizzat Süreyya Bey tarafından hazırlanan rapordur. $\mathrm{Bu}$ durum ayrıntıları ile arşiv belgeleri dâhilinde açıklanacaktır.

Kurmay Yarbay Süreyya (İlmen) Bey, 18 Mart 1912 tarihinde hazırladığ raporunda; Tayyare Mektebinin inşa edileceği yerin seçimi konusunda, kendisinin başkanlığında, Kıtaat-1 Fenniye Şubesi Müdürü İstihkâm Yarbay Refik, İstihkâm Binbaşı Mehmet Ali ve İstihkâm Binbaşı Ahmet Zeki Beylerden müteşekkil bir komisyon oluşturulduğunu ifade etmiştir (İlmen, 1982: s.10-11). Komisyonun vazifeleri arasında, havacılık hakkında araştırmalarda bulunmak, alınacak balon ile uçak seçimlerini yapmak ve hava meydanı ile tesisat işlerini düzenlemek yer almıştır (ATASE, BHK, K: 179, D: 92, F: 1-08.; ATASE, BHK, K: 179, D: 92, F: 13, 13-1.; ATASE, BHK, K: 179, D: 92, F: 1). 
Yukarıda bahsi geçen komisyon bugüne kadar yapılan çalışmalarda, sanki 1 Haziran 1911 tarihinde teşkil edilmiş gibi yansıtılarak, aktarılmıştır. Yapılan arşiv araştırmasında Süreyya Bey başkanlığında oluşturulan ilgili komisyonun Mart 1912 tarihinde teşekkül ettiği görülmektedir. Süreyya (İlmen) Bey tarafından hazırlanan 18 Mart 1912 tarihli raporda bu durumu teyit etmektedir. Arşiv taraması yapıllrken, tayyare mektep ve merkezinin yer seçimi konusunda bir komisyon teşkil edilmesi konusunun gündeme geldiği görülmektedir (ATASE, BHK, K: 328, D: 2319, F: 2-42 (43). 13 Ocak 1912 tarihinde Erkânı Harbiye Dairesi tarafindan Kıtaatı Fenniye Müfettişliğine gönderilen yazı ile Süreyya İlmen komisyonunun kuruluş süreci ortaya çıkmıştır (ATASE, BHK, K: 31, D: 2/42, F: 47.; ATASE, BHK, K: 142, D: 31-2, F: 47). Dolayısıyla bu süreç, Süreyya (İlmen) Bey başkanlığındaki komisyonun 1912 yılı içerisinde kurulduğunu, havacılık tarihindeki ilk kurum ve otorite olmadığını kanıtlamaktadır.

Süreyya (İlmen) Bey başkanlığında oluşturulan komisyon ilk olarak, Paris Askerî Ataşe Vekilinin yolladığı raporlar ve tayyare mektebi projeleri ile REP Tayyare Fabrikasının önerdiği projeyi incelemiştir. Tayyare mektebine yönelik sunulan farklı projeler arasından REP Tayyare Fabrikasının önerdiği teklif uygun görülmüştür (ATASE, BHK, K: 179, D: 92, F: 1-09). Bu çerçevede, İstanbul'a gelen REP Tayyare Fabrikası Müdürü Mösyö Simon ile toplantılar yapılarak proje üzerinde son düzeltmeler yapılmıştır. Alınan kararlar ve tasarruf tedbirleri sonucunda REP Tayyare Fabrikası yükümlülügünde 15.000 Osmanlı lirasına tayyare mektebi projesinin yaptırılabileceği ortaya çıkmıştır. Bunlara ilave olarak Mösyö Simon, kendi projelerinin kabul edilmesi şartıyla on pilot adayı subay ve on beş makinist ile marangozun kendi fabrikalarında hiçbir ücret ödenmeden yetiştirilebileceğini, İstanbul'a hemen bir mühendis ile bir öğretmen pilot göndermek suretiyle tayyare mektebini üç ay içinde kurabileceğini belirtmiştir (ATASE, BHK, K: 179, D: 92, F: 1-10-15).

Aynı dönemde, mektep projesi görüşülürken bina ve hangar inşaatı ile meydan yerinin tanzim ve tesviyesinin Erkânı Harbiye Dairesi tarafindan yaptırılması kararlaştırılmıştır. REP Tayyare Fabrikasının ise mektep araç ve gereçleri ile öğretmenleri sağlaması, okul açılıncaya kadar da pilot adayları, makinist ve marangozları Fransa'da ücretsiz yetiştirmesi teklifi uygun görülmüş, 
bu kapsamda, REP Tayyare Fabrikası Direktörü Mösyö Simon ile 18 Mart 1912 tarihinde bir mukavele imzalanmıştır (ATASE, BHK, K: 179, D: 92, F: 1-9).

Tayyare mektebi projesi karara bağlandiktan sonra, komisyon üyeleri ile Mösyö Simon İstanbul'da projenin hayata geçirileceği araziyi aramaya başlamıştır. Heyet; İstanbul'da Çırpıcı (Zeytinburnu civarı), Vidos (Güngören), Safraköy (Sefaköy), Dudullu, ve Sarıgazi civarında incelemeler yapmıştır. Yapılan bu incelemeler sonucunda, (Ayastefanos) Yeşilköy civarında bulunan Kalitarya (Şenlikköy) Köyü ile Ayamama Çiftliği arasındaki arazinin tayyare mektebi için uygun olduğuna karar verilmiştir (ATASE, BHK, K: 179, D: 92, F: 1.; Sabah Gazetesi, 17 Mart 1912). Arazinin sahibi olan Barutçuzadeler ile yapılan görüşmeler neticesinde tayyare mektebi için seçilen yer, sahibinden satın alınmıştır (İlmen, 1947: s.22).

Komisyon aynı dönemde; ordu bünyesinde yürütülen havacılık faaliyetleri, İstanbul'da inşa edilecek tayyare mektebi, tayyare bölüklerinin teşkilatı ve kadroları ile ilgili konuları içeren bir rapor hazırlamıştır. Bu raporda, teşkili planlanan birtakım için iki uçak satın alınması ve bu konuda gerekli tahsisatın sağlanarak sarf yetkisi ile beraber komisyon emrine verilmesi talep edilmiştir. Paris'e gönderilecek altı subay ile beş makinist ve marangoz için 1.500 lira yolluk ve gündelik ile 2.500 lira uçak bedeli olmak üzere, toplam 4.000 lira bulunduğu takdirde, Mösyö Simon ile hemen iki uçaklık bir sipariş sözleşmesi imzalanacağı, böylece personelin de hemen öğrenime gönderilebileceği ifade edilmiştir (Keyüsk, 1951: s.16-21).

Komisyon raporunun ardından, projeye işlerlik kazandırmak için bütçeye bir ödenek konulması gündeme gelmiştir. Ancak, devletin büyük bir mali sıkıntı içerisinde yer alması, ödeneğin teminini sıkıntıya sokmuştur. Yapılan müzakereler sonucunda mektep projesi için gerekli meblağın bir kısmının bağış yoluyla karşılanması önerisi kabul edilmiştir. Konuya ilişkin Maliye Nezaretinden 23 Mart 1912 tarihinde Sadaret makamına gönderilen yazıda, tayyarelerin Osmanlı ordusunda bulundurulmasının lüzumlu olduğundan bahisle hazinenin mevcut durumunun bütçe artırımına müsait olmadığı, konu ile ilgili harcanacak meblağın bir kısmının halkın yardımları ile temin edilebileceği, temin edilemeyen kısmının Harbiye Nezaretinin üç senelik olağanüstü bütçesindeki bazı maddelerden tasarruf edilerek karşılanmasının düşünüldüğü belirtilmiştir. Ancak, bunun yapılabilmesi 
için kanuna muvafakat maddesi eklenmesinin uygun olacağını bildirmiştir (BOA, BEO, 004019.301364.001). Sadaret makamı 24 Mart 1912 tarihinde Harbiye Nezaretine gönderdiği yazı ile kanuna konulması gereken muvafakat maddesinin hazırlanarak iletilmesini istemiştir (BOA, BEO, 004019.301364.002).

Tayyare alımı için ihtiyaç duyulan paranın temin edilmesi konusunda 27 Mart 1912 tarihinde Harbiye Nazırı Mahmut Şevket Paşa imzasıyla Sadaret makamına gönderilen yazıda; halkın yardımı dışında kalan tutarın kanuna bir muvafakat maddesi tanzim edilmesi ile karşılanmasının bir çözüm yöntemi olabileceği belirtilmiştir. Fakat aynı yazıda, gerekli olan meblağın fevkalade bütçenin yirmi birinci maddesinde yazılı olan "Seyyar Mutfaklar ve Su Süzgeçleri”" maddesinden karşılanmasının daha uygun olacağı ve bu sayede bir kanun maddesi hazırlamaya ihtiyaç kalmayacağı bildirilmiştir (BOA, BEO, 004025.301862.002.; BOA, BEO, 004025. 3012862. 001.; BOA, BEO, 004025.301862.003). Bu durum, tayyare mektebi projesinin bir kısmının halkın yardımları ile bir kısmının ise bütçeden karşıllanacağını göstermektedir.

Harbiye Nazırı Mahmut Şevket Paşa, uçak alımı için açılan bağış kampanyasına öncülük ederek 2.700 kuruş ile kampanyayı başlatmıştır. Ayrıca Mahmut Şevket Paşa ve Harbiye Nezareti personeli altı ay süreyle maaşlarının dörtte birini uçak alımı kampanyasına bağışlamıştır (Sabah Gazetesi, 15 Mart 1912). Bu kapsamda Mahmut Şevket Paşa, Donanma-y1 Osmanî Muavenet-i Milliye Cemiyeti'ne 14 Mart 1912 tarihinde gönderdiği bir yazı ile Cemiyetin donanma dışında uçak alımı için de yardım toplamasını talep etmiştir (Aydar, 1948: s.137.; Keyüsk, 1951: s.27-28.; Kural, 1975: s.161). Bunun üzerine Cemiyet İdare Heyeti tarafindan yapılan toplantı sonucu, istek kabul edilerek onaylanmışıtır. Cemiyet, şubelerine toplanacak yardımlar için ayrı bir hesap açtırmalarını istemiştir (.Tanin Gazetesi, 18 Mart 1912). Bu sırada, satın alınacak uçağa "Osmanlı" adının verilmesi kararlaştırılmıştır (Sabah Gazetesi, 16 Mart 1912). Aynı dönemde uçaklar için açılan bağış kampanyasına Padişah V. Mehmet Reşad tarafından da destek olunarak 1.000 lira bağışlanmıştır (Tanin Gazetesi, 19 Mart 1912.; Sabah Gazetesi, 19 Mart 1912).

Tayyare Mektebi ve havacılık merkezinin kuruluşunda büyük gayretleri ve çalışmaları olan Kurmay Yarbay Süreyya (İlmen) Bey de bağış kampanyasını duyurmak ve ilgiyi tayyareciliğe çekmek amaciyla Ceride-i Askeriye'de, 
“Osmanlıların Büyük Bir İstikbali de Tayyarelerdedir!” adlı havacılıkla ilgili ilk makaleyi yayımlamıştır. Süreyya Bey makalede; uçakların gelecekte ordular içerisinde önemli görevler alacağını, deniz ve kara hâkimiyetinin yanında hava hâkimiyetinin de önem arz ettiğini, Avrupa devletlerinin havacılık için büyük bütçeler ayırdıklarını, komşu ülkelerden Bulgaristan, Yunanistan ve Sırbistan'ın uçak almak amacıyla girişimde bulunduklarını belirtmiştir. Süreyya (İlmen) Bey, olası bir savaşta uçakların hem keşif hem de bombardıman maksadıyla kullanılabileceğini, yardım kampanyası sayesinde Osmanlı ordusunda tayyareciliğin ilerleyeceğini ve böylece birçok tayyare bölüklerine sahip olunabileceğini beyan etmiştir. Ayrıca Süreyya (İlmen) Bey, tüm ordu mensuplarının altı aylık maaşlarının dörtte birini kampanyaya bağışlamalarını istemiştir (Ceride-i Askeriye, 21 Mart 1912.; İlmen, 1947: s.24-28).

Bağış kampanyasından toplanan para ile REP Tayyare Fabrikasından iki uçak alımı ile altı subay ve beş marangoz ile makinistin, fabrikanın Uçuş Okulunda ücretsiz öğrenim görmelerine ilişkin sözleşme imzalanabilmiştir. Uçak bedelleri ile Paris'e gönderilecek personele verilecek yolluk ve yevmiye toplamı olan 4.000 liradan geri kalan 3.000 lira, 20 Mart 1912 tarihinde Harbiye Nazırı Mahmut Şevket Paşa tarafindan Donanma Cemiyetinden denkleştirilerek REP Tayyare Fabrikası ile anlaşmanın yürürlüğe girmesi sağlanmıştır. Anlaşmaya konulan bir madde ile uçaklardan birinin, 27 Nisan 1912 tarihinde yapılacak olan padişahın tahta çıkış yıl dönümündeki (cülusu hümayun) törene katılmak üzere acele bir şekilde hazırlanarak fabrikanın sağlayacağı bir pilotla İstanbul'a gönderilmesi ve ilgili günde tören alanı üzerinde gösteri uçuşu yapması kararlaştırılmıştır (Kurter, 2009: s.84).

Uçak bağışı kampanyası kısa sürede etkisini göstermiştir. Nitekim 25 Mart 1912 tarihinde Drama Mutasarrıfı Tahsin Bey imzasıyla Dâhiliye Nezaretine gönderilen yazıda, milletin ve vatanın selameti için Drama Sancağının 1.000 lira göndererek, alınacak tayyareye Tarık Bin Ziyad adının verilmesini istediklerini belirtmiştir (BOA, DH.MTV. D.: 48/1,12).

Uçak alımı için bağış kampanyası devam ederken 12 Mart 1912 tarihinde Fransa'dan satın alınan iki adet Deperdussin uçağı İstanbul'a getirilerek Hasköy’deki Piri Paşa Ambarlarına konulmuştur. Gelen uçaklardan biri iki kişilik askerî uçak, diğeri ise tek kişilik eğitim uçağıdır. Satın alınan uçaklardan iki kişilik 
Deperdussin uçağına "Osmanlı" adı verilmiştir. Bu sırada Komisyon Başkanı Kurmay Yarbay Süreyya (İlmen) Bey, 13 Mart 1912 tarihinde Paris Askerî Ataşeliğine gönderdiği bir telgrafla Yüzbaşı Fesa (Evrensev) ile Üsteğmen Yusuf Kenan Bey'i, satın alınan uçakları teslim almak üzere İstanbul'a çağırmıştır. Bunun üzerine Fransa'dan hareket eden Fesa ve Yusuf Kenan Beyler, İstanbul'a gelerek 20 Nisan 1912 tarihinde uçakları teslim almıştır. Teslim alınan uçaklar Ayastefanos'a taşınmış, hangar inşaatı yeni başladığından uçaklar sandıklar içerisinde muhafazaya alınmıştır. Tayyare Mektebinin ilk öğretmenleri de bu iki subay olmuştur (İlmen, 1947: s.23.; Kural, 1975: s.165-167). Aynı dönem içinde pist ve hangar inşaatı da başlamıştır (Sabah Gazetesi, 28 Mart 1912). Sonuçta kısa bir süre içerisinde 4,5 metre yüksekliğinde, 16 metre genişliğinde iki uçak hangarı ile 250 metre genişliğinde 1.500 metre uzunluğunda bir pist inşa edilmiştir (ATASE, BHK, K: 179, D: 92, F: 13).

Aynı tarihlerde REP Tayyare Fabrikası Direktörü Mösyö Simon'un uçak satın alınması karşı1lı̆ında personele ücretsiz eğitim verilmesi konusundaki taahhüdü kapsamında, İstihkâm Kolağası Cemal, Piyade Yüzbaşı Refik, Piyade Yüzbaşı Fevzi, Topçu Üsteğmen Nuri ile İstihkâm Üsteğmen Salim (Batur), beş makinist ve marangoz adayı ile birlikte 11 Nisan 1912 tarihinde Paris'e gönderilmiştir (ATASE, BHK, K: 110, D: 10, F: 1-1).

15 Nisan 1912 tarihinde öğrenimleri başlayan pilot adaylarının eğitimi Paris civarındaki Buc'te devam etmiştir. Altıncı pilot adayı, Paris Askerî Ataşe Vekili'nin önerisi üzerine, o günlerde Fransa'da staj görmekte olan Topçu Yüzbaş1 Salim (İlkuçan) Bey olmuştur. Bu sırada REP Fabrikası ile yapılan görüşmeler sonucunda iki subayın daha, ücretsiz eğitim alması kararlaştırılmıştır (ATASE, BHK, K: 53, D: 249, F: 40-1). Bu kapsamda, Paris yakınlarındaki Versailles Topçu Okulunda bulunan Topçu Üsteğmen Mithat Nuri (Tuncel) ile İstanbul'dan gönderilen Süvari Üsteğmen Mehmet Şükrü Bey'in pilotaj eğitimine başlaması uygun görülmüsşür (ATASE, BHK, K: 673, D: 172, F: 002-05). Böylece, toplam sekiz subay Buc'te bulunan REP Fabrikasında pilotluk öğrenimine başlamıştır (ATASE, BHK, K: 179, D: 92, F: 1-53). Fransa'ya eğitime gönderilen ikinci kafile personel, Temmuz ve Ekim 1912 tarihlerinde pilotaj kurslarını bitirerek yurda dönmüşlerdir (Kansu vd., 2006: s.127). 
Sultan V. Mehmet Reşad'ın tahta çıkış y1l dönümü merasimine yetiştirilmesi için Yeşilköy'deki çalışmalar hızlı bir şekilde tamamlanmıştır. Daha önce REP Tayyare Fabrikası Direktörü Mösyö Simon ile yapılan anlaşma gereği, yabancı bir pilotla bir adet REP uçağının törende uçması planlanmıştır. Türk pilotlarının tecrübesizliği ve gösteriye katılması düşünülen uçaklardan birinin motor gücünün zayıflığı sebebiyle böyle bir karar alınmıştır. (İlmen, 1947: s.33.; Kansu vd., 2006: s.125). Bu sırada REP Tayyare Fabrikası, cülus töreninde uçacak, sipariş edilen iki adet tayyareden birinin 16 Nisan 1912 tarihinde yola çıkarıldığını bildirmiştir (BOA, DH.ID.00019.2.00061.002). 19-20 Nisan 1912 tarihinde REP uçağı ile törende uçacak olan Pilot Gordon Bell, iki makinistle beraber İstanbul'a gelmiştir. Fransa'dan gelen uçağın montaj ve diğer hazırlıkları beş altı gün içinde tamamlanmıştır. Hazırlanan uçağın ilk tecrübesi, 26 Nisan 1912 tarihinde sabah saatlerinde, Kurmay Yarbay Süreyya Bey ve komisyon üyelerinin önünde gerçekleştirilmiştir (Kurter, 2009: s.87). Pilot Gordon Bell, başarılı bir uçuş yaparak Yeşilköy civarında yaklaşık yüz metre irtifada birkaç kez dolaşmış ve sonra yere inmiş, ardından tekrar havalanarak önce beş yüz, sonra bin metre yüksekliğe çıkıp Ayvansaray, Beyoğlu ve Üsküdar üzerinden geçerek Marmara Denizi'ni takiben 45 dakika sonra Yeşilköy'e inmiştir. Bu başarılı uçuş, Süreyya Bey tarafından bizzat Harbiye Nazırı Mahmut Şevket Paşa'ya bildirilmiştir (İlmen, 1947: s.29-30).

Fransız Pilot Gordon Bell'in başarılı uçuş tecrübesinin ardından Mahmut Şevket Paşa maiyeti ile birlikte Yeşilköy’e gelmiştir. Önce, inşaatı devam etmekte olan mektep ve hangarları denetlemiş, yapılan çalışmalar hakkında bilgi aldıktan sonra personeli takdir ederek okulun daha da büyütülmesini istemiştir. Teftişten hemen sonra Pilot Gordon Bell, "Ordu" adı verilen REP uçağı ile Mahmut Şevket Paşa'ya 45 dakika süren bir gösteri uçuşu yapmıştır. Bu sırada İlk Türk Pilotu Yüzbaş1 Fesa Bey tarafından da Deperdussin model, Prens Celâlettin isimli uçak ile bir uçuş gerçekleştirilmiştir (Keyüsk, 1951: s.24-26.; Kansu, 2006: s.124-127.; Aydar, 1948: s.26). Gorden Bell hatıralarında; “...Avrupa'dan henüz dönmüş olan Fesa Bey'in Deperdussin tayyaresiyle yaptığı uçuşun, özellikle göze çarptığını" belirtmiştir (Primi, Tarih belirtilmemiş: s.4). Böylece, bir Türk pilotu tarafindan 
Türk göklerindeki ilk uçuş gerçekleştirilmiştir* (Türkiye Gazetesi, 27 Nisan 2000.; Hürriyet Gazetesi, 29 Nisan 2000).

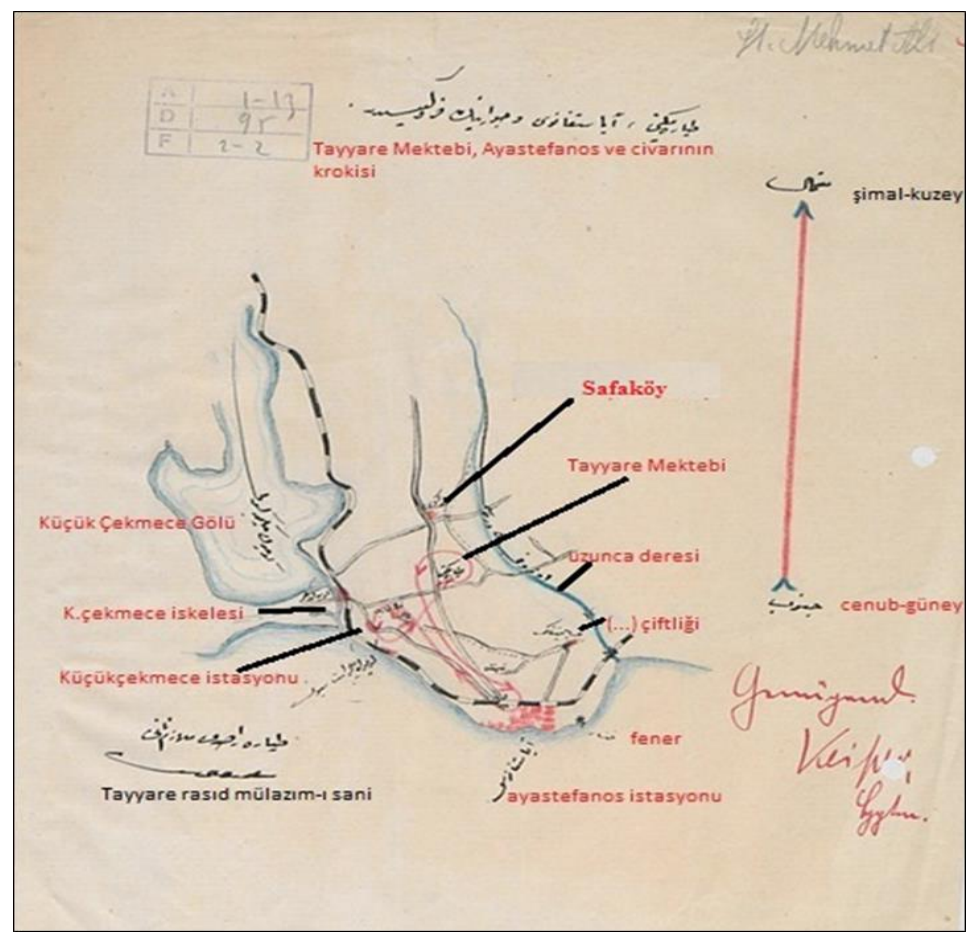

Yeşilköy (Ayastefanos) Tayyare Mektebi ve Civarının Krokisi (ATASE, BHK, K: 1405, D: 70, F: 02-02).

\footnotetext{
* Türk Hava Kuvvetlerinin İlk Pilotu Yüzbaşı Mehmet Fesa Evrensev'in Türk semalarında 26 Nisan 1912 tarihinde yaptığı bu ilk uçuş, günümüzde "Pilotlar Günü" olarak kutlanmaktadır. Türkiye Hava Yolu Pilotları Derneği (TALPA) tarafından 1 Mart 2000 tarihinde, Türk havacılarının birlik ve beraberliğinin bir sembolü olarak Türk semalarında yapılan ilk uçuşun pilotlar günü olarak kabul edilmesine yönelik bir talep olmuştur. Bu kapsamda Hava Kuvvetleri Komutanlığ tarafindan yapılan inceleme ve araştırma sonucunda, 23'üncü Hava Kuvvetleri Komutanı Orgeneral Ergin Celasin tarafindan, "26 Nisan gününün, tüm Türk havacılarının birlik ve beraberliğinin sembolü olarak Türkiye Pilotlar Günü olarak ilan edilmesi kararlaştırılmış̧ır. Türkiye Hava Yolu Pilotları Derneği (TALPA), Avrupa Kokpit Kuruluşu (ECA) ve Uluslararası Hava Yolları Pilotları Federasyonu (IFALPA) 26 Nisan 2014 tarihinde, ilgili günün "Uluslararası Pilotlar Günü" olarak kutlanmasını destekleyeceklerini belirtmiştir (Cumhuriyet Gazetesi, 27 Nisan 2000).
} 
Sultan V. Mehmet Reşad'ın tahta çıkış yıl dönümü için 27 Nisan 1912 tarihinde Hürriyet-i Ebediye Tepesi üzerinde planlanan hava gösterisi, Pilot Gordon Bell tarafından gerçekleştirilmiştir. Uçuş öncesinde "Ordu" isimli REP uçağının kanatlarına Osmanlı Devleti'nin bayrakları takılmıştır. Hazırlıklar sonrasında Yeşilköy'den kalkan uçak, Hürriyet-i Ebediye Tepesi, Beyoğlu ve Üsküdar üzerinden geçerek hava gösterisini tamamlamıştır. Gordon Bell'in yaptığı bu uçuş, Padişah ve halk tarafından yoğun ilgi ile izlenmiş ve büyük dikkat çekmiştir (Sabah Gazetesi, 28 Nisan 1912.; Tanin Gazetesi, 28 Nisan 1912.; İlmen, 1947: s.33-37).

Padişahın tahta çıkış yıl dönümünü merasiminden sonra 6 Mayıs 1912 tarihinde, Harbiye Nazırı Mahmut Şevket Paşa'nın talimatı ile Kurmay Yarbay Süreyya (İlmen) ile İstihkâm Binbaşı Mehmet Ali Beyler, uçak ve balon satın alınması için Avrupa'ya gönderilmiştir (İlmen, 1947: s.50-51).

Aynı dönemde Yeşilköy'de inşaatı 1912 yılı ortalarında tamamlanan ancak eksiklikleri giderilmeye çalışılan Tayyare Mektebi 3 Temmuz 1912 tarihinde eğitime başlamıştır. Tayyare Mektebi'nin açılması ile bugünkü Hava Harp Okulu'nun temelleri atılmıştır. Bu sırada, Piyade Binbaşı Mehmet Cemal Bey, Tayyare Mektebine müdür olarak tayin edilmiştir (Uçarol, 1974: s.19-20.; Gediz, Uçan Türk Dergisi, s.47). Böylece, uzun uğraşlar sonucunda Osmanlı Ordusu kendi havacı personelini yetiştirebileceği bir mektep ve merkeze kavuşmuştur.

\section{Sonuç}

Atatürk, "Tarih yazmak, tarih yapmak kadar mühimdir, yazan yapana sadık kalmazsa, değişmeyen hakikat, insanlığı şaşırtacak bir mahiyet alır (Kocatürk, 1999: s.163)." diyerek tarih yazımının önem ve değerini ortaya koymuştur.

Bilimsel tarih metodolojisi kapsamında çalışmalar yapılabilmesi için, olayların kronolojik olarak anlatılmasının yanında, birincil kaynaklara dayalı olarak ifade edilmesi gerekir. Bu durumu ortaya koymanın en önemli ve en güvenilir yolu belge ve doküman kaynaklı olarak çalışmaktan geçer. Birincil kaynak belge ve dokümana dayanmayan bir tarih aktarımı, söylentiden öte bir değer taşımaz. Bu bağlamda, Türk askerî havacıllğının hangi şartlarda kurulduğu ve teşkilatlanarak şekillendiği konusu, arşiv belgeleri ışığında değerlendirildiğinde 
daha kolay anlaşılacaktır. Arşiv belgelerinin varlığı kadar, o belgelerin değerlendirilmesi de büyük önem arz etmektedir. Bu kapsamda, tarih yazımında birincil kaynak verilerin yanlış yorumlanmasının, doğru bilginin farklı bir mahiyet ve özellik kazanmasına yol açabileceği de bir gerçektir. Dolayısıyla tarihi belgelerin ve verilerin iyi bir şekilde tahlil, tenkit ve analiz edilmesi ile gerçeğe ulaşılabileceği evrensel ve bilimsel bir hakikattir.

Osmanlı ordusunda askerî havacılık faaliyetlerinin başlaması ve kurumsal bir yapıya kavuşturulması belirli bir zaman ve çabayı gerektirmiştir. Elimizdeki belgeler 1şığında, söz konusu çalışmaların 1909 yılından itibaren başladığ anlaşılmaktadır. Havacılık faaliyetlerinin Osmanlı ordusunun ilgi sahasına girmesi ilk olarak Avrupalı devletlerin başkentlerinde görev yapan askerî ataşelerin Harbiye Nezaretine gönderdiği raporlarla olmuştur. $\mathrm{Bu}$ raporlardan, Batı ordularındaki teknik ve teknolojik gelişmelerin çok yakından takip edildiği ve Osmanlı ordusunun batıda kullanılmaya başlanan kara ve hava harp silahlarından faydalanma arzu ve kararı açıkça görülmektedir. Yine bu belgelerden askerî havacılık ile ilgili dönemin bütçesindeki para sıkıntısı nedeniyle uzun uğraşlar neticesinde gerçekleştirilen pek çok planlamanın arzu edilen zamanda hayata geçirilemeyişine de tanıklık etmekteyiz. Yaşanan maddi sıkıntılara rağmen Osmanlı ordusunun modern harp silahları ile teçhiz edilmesi düşüncesinden asla vazgeçilmemiş, yaşanılan imkânsızlıklara rağmen askerî havacılığın kuruluşu ve teşkilatlanması konusunda kısa bir süre içerisinde büyük bir başarı ile çok önemli mesafeler alınmıştır.

1909 yılından itibaren Askerî ataşe raporları ile başlayan bu süreç Harbiye Nezaretinin öncülügü̈nde kurumsal bir anlayışla ele alınmış ve havacılık teşkilatının kuruluşunu için çalışmalar hızlandırılmıştır. Bu kapsamda, Harbiye Nezareti Kıtaat-1 Fenniye ve Mevaki-i Müstahkeme Müfettişliğinin 1 Haziran 1911 tarihli ilamı (ATASE, BHK, K:328, D: 2319, F: 2-15) ile havacılık çalışmaları kapsamında en somut adım atılmış ve bu kapsamda Avrupa'ya pilotaj eğitimi için gönderilecek personelin seçimi ve tayyarecilik faaliyetleri için bir komisyon teşkil edilmesi kararlaştırılmıştır.

Havacılık faaliyetleri kapsamında ilk defa teşkil edilen bu tayyarecilik komisyonu, 1960 yılında alınan kararla Türk Hava Kuvvetlerinin ilk teşkilatı olarak kabul edilmiş ve Türk Hava Kuvvetlerinin kuruluş y1l dönümü olarak 
kutlanmaya başlanmıştır. Havacılık tarihindeki bu ilk komisyonun yapılan arşiv araştırmasında Erkânı Harbiye Dairesi 2'nci Şubesi'nde görevli Kurmay Yarbay İsmail Bey başkanlığında teşkil edildiği tespit edilmiştir. Oysa 1 Haziran 1911 tarihinde teşkil edilen bu komisyonla ilgili olarak bugüne kadar yapılan çalışmalarda; Türk Hava Kuvvetlerinin temelini oluşturduğu kabul edilen ilk havacılık komisyonunun Erkânı Harbiye Dairesi 2'nci Şubesinde görev yapan Kurmay Yarbay Süreyya (İlmen) Bey tarafından kurulduğu tezi kabul edilmiştir. Kurmay Yarbay Süreyya (İlmen) Türk Havacılık teşkilatının kuruluş sürecinde çok önemli ve büyük hizmetlerde bulunmuş çok değerli ve iyi yetişmiş bir subaydır. Havacılık teşkilatının kuruluş sürecinin kuşkusuz ki en önemli simalarındandır. Türk askerî havacılık tarihi yazılırken Süreyya İlmen'in kurucular arasında isminin yer alması çok yerinde bir değerlendirmedir. Ancak yapılan araştırma ve incelemelerde Kurmay Yarbay Süreyya Bey başkanlığında oluşturulan komisyonun Mart 1912 tarihinde kurulduğu görülmüştür. Nitekim dönemin askerî yazışmalarından anlaşıldığı üzere, Kurmay Yarbay Süreyya Bey Mayıs 1911 tarihinden itibaren Erkânı Harbiye Dairesi 2'nci Şubesinde görevli iken askerî havacılık faaliyetleri içerisinde yer almıştır. Fakat Türk Hava Kuvvetlerinin kuruluş yıldönümü olarak kabul edilen 1 Haziran 1911 tarihinde teşkil edilen komisyonun, Süreyya Bey ile aynı şubede görev yapan Kurmay Yarbay İsmail Bey başkanlığında oluşturulduğu dönemin belgelerinden anlaşılmaktadır.

$\mathrm{Bu}$ kapsamda, Türk askerî havacılığının kuruluşuna yönelik birincil kaynaklı bir yazım tarzının günümüze kadar ortaya konmaması, bunun yanında belge ve bilgilerin yanlış yorumlanmasının kuruluş sürecinin tam ve net bir şekilde ortaya konulmasını engellediği tespit edilmiştir. Havacılığın kuruluşu konusundaki tahlil ve analiz yanlışının, tenkit süzgecinden geçirilmeden devam ettirilmesi bu makalenin yazımındaki en büyük etken olmuştur. Yapılan çalışma ile Türk askerî havacılığının kuruluşu birincil el kaynaklara dayalı olarak, bilimsel analiz ve değerlendirme yöntemleri kullanılarak ortaya konulmuştur.

\section{Extended Summary}

The practical use of the aircraft for the first time in the Picardie Maneuver in France in 1910 inspired the Ottoman Empire to set up the aviation organization, 
supply airplanes and provide pilotage training to the military men as much as the world states. In this context, Ministry of Defense initiated workings in order to establish an Aviation Commission, Aviation School and Centre for organizing the aviation activities.

Turkish General Staff of Ministry of Defense accelerated the workings for the establishment of military aviation by taking into consideration the importance of the aviation in the near future. In this context, it was stated that in the letter sent to the Inspectorate of Technical Services and Fortified Area of Ministry of Defense, it was necessary to train aviator personnel and to send a few officers to the Europe next year for their training in order to keep up with European Countries.

In the same period, with a circular issued by the Turkish General Staff on the 13th of February 1911, it was asked to determine two officers from each army in order to choose the candidates who were going to be sent to the Europe for the Aviation Training. Not feeling dizzy due to the swing and the sea, having courage and patience and a good knowledge of tactics were stated as the required qualifications. In addition, the officers who were willing to learn the aviation and knew foreign language were asked to apply. Turkish General Staff planned to send two personnel at the rank of lieutenant and captain who had the required qualification to Europe for pilotage education after subjecting them to an exam.

The Inspectorate of Technical Services and Fortified Area was appointed with the letter dated 28 May 1911 in order to carry out the election examinations and aviation activities. With regard to this letter, on the basis of the recommendation of the Inspectorate of Technical Services and Fortified Area and the appointment of the Turkish General Staff, it was decided to establish a commission on the 1st June of 1911 for the execution and follow-up the activities. This Commission was accepted as the first organization of Military Aviation in Ottoman Army.

It was stated that the commission which was mentioned in many researches made up to date about the founding of Turkish Military Aviation was founded under the presidency of Staff Lieutenant Colonel Süreyya İlmen and constituted on the 1st June of 1911. The publications expressing this opinion gave reference reports of Staff Lieutenant Colonel Süreyya İlmen and General Staff ATASE Archive and the book of "The History of Aviation and Aerostation in Turkey" 
belonging to Süreyya İlmen. However, in the book of Staff Lieutenant Colonel Süreyya İlmen, he didn't give a date about the founding date of Aviation Commission but in the works made about the Aviation History under the presidency of him, the founding date of Aviation Commission was stated as 1st June of 1911. In the upcoming aspects it can be seen that the Commission founded under the presidency of Staff Lieutenant Colonel Süreyya İlmen who had an important role in the founding period, consisted in March 1912 and had an impact on the founding of Flight School and Centre. Therefore, the first commission founded in the history of Turkish Military Aviation was founded not by Süreyya İlmen, but by Staff Lieutenant Colonel İsmail Bey.

It is seen that the date of 1st June of 1911, which was accepted as the foundation of Turkish Military Aviation was also accepted as the foundation of Turkish Air Forces in 1960. However, when the report of Süreyya İlmen in ATASE Archives was examined, he didn't give a complete and precise date, but he just mentioned that he was charged with aviation works at the time of sending two officers, Captain Sefa and Lieutenant Yusuf Kenan, to the Europe for the pilotage training. Based on the statement of Mr. Süreyya, the commission which was founded under the presidency of him was stated as if this commission had been founded on the 1st June of 1911 with a strained interpretation. It is seen that this situation originating from a misinterpretation has been the subject of many studies, researches and academic works, but it has been transferred to various works without being examined thoroughly. It was determined that the Aviation commission founded under the presidency of Staff Lieutenant Colonel Süreyya İlmen was founded for the establishment of Flight School and Centre in 1912.

It is evaluated that the first aviation commission was not founded by Staff Lieutenant Colonel Süreyya İlmen but founded by Staff Lieutenant Colonel İsmail working in the 2snd branch of Ministry of Defense with the decision taken on the 1st June of 1911 (19 May 1327). It has been seen that there are many important documents and archival letters as a result of the researches. In the examination made in the archive of ATASE, it was determined that a commission was founded in order to measure and determine the ability to the engines and the knowledge of foreign language of the personnel to be sent to the Europe for the aviation activities and pilotage education on the 1st June of 1911. 
The Turkish Air Forces was laid down with the decision of founding the Aviation Commission expressed in the related document. The most important document showing that the Commission was founded under the presidency of Staff Lieutenant Colonel İsmail is the document dated 29 June 1911 containing the exam results which aimed to determine the abilities to the Aviation and knowledge of foreign language of the personnel to be sent to the Europe. There were exam results in the related document. In addition, the names of the aviation commission members under the presidency of Staff Lieutenant Colonel İsmail were stated in this document. In this first commission of Aviation founded under the presidency of Staff Lieutenant Colonel İsmail, there were Major Ali from the members of Technical Services and Fortified Area, Major Ali Riza-Projector Inspector of Technical Services Inspectorate, Mehmed Şevki-Electric and Projector Teacher and İbrahim Fahri-Electric and Projector Assistant Teacher. Therefore, the abovementioned people consisted the first aviation commission for the aviation activities in the history of Ottoman Army.

In the exam made on 28 June 1911, Cavalry Captain Mehmet Fesa (Evrensev) with 92 grades and Engineer Lieutenant Yusuf Kenan with 91 grades deserved to get training in Europe. Despite the decision of sending the staff to the Germany, they were sent to the Flight School of Bleriot Aircraft Factory on 9 June 1911 in France after relevant personnel received health reports because of the fact that the Aircraft technology was much more advanced and the training cost is much lower than the other countries.

The first commission founded during the establishment process of Turkish Military Aviation evaluated that the personnel could be trained in a center to be opened in İstanbul due to the economic troubles of the Ottoman State after the election activities of personnel to be sent to Europe under the presidency of Staff Lieutenant Colonel İsmail. Within this scope, founding another commission for the opening of a Flight School and Center in İstanbul became the main topic of the time. This process led up to founding a new comission under the presidency of Staff Lieutenant Colonel Süreyya İlmen.

In the article sent to the Inspector of Technical Services on 13 January 1912 by the General Staff, it was stated that two aircrafts were going to be bought for the construction of the Flight School, an agreement was made about recruiting 
an aviator and a machinist and officers who were studing in Paris were going to return soon. In addition, it was stated that a contract was made quarterly with the teacher who was scheduled to work at the Flight School and preparations for construction were required to be started by the arrival of the teacher to İstanbul. In this context, it was stated that a convenient square place for one kilometer long and half kilometer wide protected from various wind currents around İstanbul was going to be chosen by constituting a comission consisting of two engineer officers to be inducted from the Technical Services and General Staff.

As a result of decision taken above, a commission consisting of the Director of Technical Services-Engineer Lieutenant Colonel Refik, Engineer Major Mehmet Ali and Engineer Ahmet Zeki, was founded under the presidency of Staff Lieutenant Colonel Süreyya İlmen for the construction place of Flight School. The mentioned commission was stated in the workings made up to today as if the commission had been founded on 1st June of 1911. In the Archive research, it is seen that the commission was organized on March 1912. The report prepared by Mr. Süreyya in the ATASE Archive dated 18 March 1912, confirms this situation. While making Archive research, it was seen that organizing a commission in order to determine the place of Flight School and Centre, became the topic of the time.

The Flight School which was completed in the midst of 1912, started to give education in 3 July 1912. With the opening of Flight School, the foundation of today's Air Forces Academy was laid down. Meanwhile, the infantry captain Mehmet Celal was appointed as the Director of the Flight School. Thus, the Ottoman Army attained a school and a center where the Army could raise its own aviation personnel as a result of long efforts.

As a result, the first aircraft comission the basis of Turkish Air Forces established on 1 June 1911 after the decision taken by Kitaat Fenniye Inspectorate under the chairman of not by the Staff Liutenant Colonel Süreyya (İlmen), but by the Staff Lieutenant Colonel İsmail. Thus, the first formation of Turkish Air Forces was founded.

The foundation process of the military aviation organization in the Ottoman Army required a dedicated work. Many people such as Staff Lieutenant Colonel İsmail and Staff Lieutenant Colonel Süreyya İlmen worked in this process and made a significant contribution. The works started in 1909, gained a 
momentum in 1911 and after 1912, important institutions related to the aviation were opened. This institutionalization studies within the army were carried out on the basis of the joint study of Technical Services and Fortified Area Inspectorate of Ministry of Defense and General Staff Department of Ministry of Defense. The first commission with the aim of carrying out the aviation activities and sending personnel to the Europe for pilotage training was founded under the presidency of Staff Lieutenant Colonel İsmail working at the 2nd Branch of General Staff Department. In the upcoming period, the aviation commission founded under the presidency of Staff Lieutenant Colonel Süreyya İlmen on March 1912 led to the foundation of Flight School and Center. Thus, the institutionalization and organization activities of Turkish Military Aviation process started with these studies. In this study, the foundation process of Turkish Military Aviation was explained completely and precisely in the light of archive texts.

\section{Kaynakça}

\section{Arşiv Belgeleri}

ATASE Arşivi, BHK, Klasör: 328, Dosya: 23/2319, Fihrist: 2-7

ATASE Arşivi, BHK, Klasör: 328, Dosya: 23/2319, Fihrist: 2-9

ATASE Arşivi, BHK, Klasör: 328, Dosya: 23/2319, Fihrist: 2-8

ATASE Arşivi, BHK, Klasör: 328, Dosya: 2319, Fihrist: 2-10

ATASE Arşivi, BHK, Klasör: 328, Dosya: 2319, Fihrist: 2-15

ATASE Arşivi, BHK, Klasör: 179, Dosya: 92, Fihrist: 1-08

ATASE Arşivi, BHK, Klasör: 179, Dosya: 92, Fihrist: 001-09

ATASE Arşivi, BHK, Klasör: 179, Dosya: 92, Fihrist: 001-10

ATASE Arşivi, BHK, Klasör: 179, Dosya: 92, Fihrist: 001-11

ATASE Arşivi, BHK, Klasör: 179, Dosya: 92, Fihrist: 001-12

ATASE Arşivi, BHK, Klasör: 179, Dosya: 92, Fihrist: 001-13

ATASE Arşivi, BHK, Klasör: 179, Dosya: 92, Fihrist: 001-14

ATASE Arşivi, BHK, Klasör: 179, Dosya: 92, Fihrist: 001-15

ATASE Arşivi, BHK, Klasör: 179, Dosya: 92, Fihrist: 013

ATASE Arşivi, BHK, Klasör: 179, Dosya: 92, Fihrist: 013-01

ATASE Arşivi, BHK, Klasör: 179, Dosya: 92, Fihrist: 013-02. 
ATASE Arşivi, BHK, Klasör: 328, Dosya: 2319, Fihrist: 2-22. ATASE Arşivi, BHK, Klasör: 2319, Dosya: 328-23, Fihrist: 2-23. ATASE Arşivi, BHK, Klasör: 328, Dosya: 23/2319, Fihrist: 2-11 ATASE Arşivi, BHK, Klasör: 328, Dosya: 23/2319, Fihrist: 2-13. ATASE Arşivi, BHK, Klasör: 328, Dosya: 23/2319, Fihrist: 2-19 ATASE Arşivi, BHK, Klasör: 3, Dosya: 7/13, Fihrist: 19-1 ATASE Arşivi, BHK, Klasör: 31, Dosya: 2/42, Fihrist: 47 ATASE Arşivi, BHK, Klasör: 142, Dosya: 31-2, Fihrist: 47 ATASE Arşivi, BHK, Klasör: 179, Dosya: 92, Fihrist: 1 ATASE Arşivi, BHK, Klasör: 179, Dosya: 92, Fihrist: 1-1 ATASE Arşivi, BHK, Klasör: 179, Dosya: 92, Fihrist: 1-02 ATASE Arşivi, BHK, Klasör: 179, Dosya: 92, Fihrist: 1-03 ATASE Arşivi, BHK, Klasör: 179, Dosya: 92, Fihrist: 1-04 ATASE Arşivi, BHK, Klasör: 179, Dosya: 92, Fihrist: 1-05 ATASE Arşivi, BHK, Klasör: 179, Dosya: 92, Fihrist: 1-06 ATASE Arşivi, BHK, Klasör: 179, Dosya: 92, Fihrist: 1-07 ATASE Arşivi, BHK, Klasör: 179, Dosya: 92, Fihrist: 1-08 ATASE Arşivi, BHK, Klasör: 179, Dosya: 92, Fihrist: 13, 13-1 ATASE Arşivi, BHK, Klasör: 179, Dosya: 92, Fihrist: 1. ATASE Arşivi, BHK, Klasör: 179, Dosya: 92, Fihrist: 1-10-15 ATASE Arşivi, BHK, Klasör: 179, Dosya: 92, Fihrist: 1-9 ATASE Arşivi, BHK, Klasör: 110, Dosya: 10, Fihrist: 1-1 ATASE Arşivi, BHK, Klasör: 53, Dosya: 249, Fihrist: 40-1 ATASE Arşivi, BHK, Klasör: 673, Dosya: 172, Fihrist: 002-05 ATASE Arşivi, BHK, Klasör: 179, Dosya: 92, Fihrist: 1-53 ATASE Arşivi, BHK, Klasör: 1405, Dosya: 70, Fihrist: 02-02 ATASE Arşivi, BHK, Klasör: 328, Dosya: 2319, Fihrist: 2-42 ATASE Arşivi, BHK, Klasör: 328, Dosya: 2319, Fihrist: 2-43 ATASE Arşivi, BHK, Klasör: 328, Dosya: 2319, Fihrist: 2-43a ATASE Arşivi, BHK, Klasör: 328, Dosya: 2319, Fihrist: 2-42a Başbakanlık Osmanlı Arşivi, Hariciye Nezareti Hukuk Müşavirliği İstişare Odası, BOA, HR.HMŞ.İ̧̧O. Dosya: 120/31 
Başbakanlık Osmanlı Arşivi, BOA, Bab-1 Âli Evrak Odası (BEO), Harbiye No.: 266696

Başbakanlık Osmanlı Arşivi, BOA, BEO, 266820

Başbakanlık Osmanlı Arşivi, BOA, Dosya No.: 13-2/35

Başbakanlık Osmanlı Arşivi, BOA, BEO, No: 281907

Başbakanlık Osmanlı Arşivi, Hariciye Nezareti Hukuk Müşavirliği İstişare Odası, BOA, HR. HMŞ. İSO., No.: 103/1-3

Başbakanlık Osmanlı Arşivi, BOA, HR.SFR.(3).656.001.003

Başbakanlık Osmanlı Arşivi, BOA, HR.SFR.(3).656.001.00

Başbakanlık Osmanlı Arşivi, BOA, HR.SFR. (3). 00656. 00001.001

Başbakanlık Osmanlı Arşivi, BOA, HR.SFR. (3). 00656. 00001.007

Başbakanlık Osmanlı Arşivi, BEO, 4013.300907.002

Başbakanlık Osmanlı Arşivi, BEO, 4005.300301.001

Başbakanlık Osmanlı Arşivi, BEO, 004017.901212.003

Başbakanlık Osmanlı Arşivi, BEO, 004013.300924.002

Başbakanlık Osmanlı Arşivi, BEO, 4013.300907.001

Başbakanlık Osmanlı Arşivi, BEO, 004013.300924.003

Başbakanlık Osmanlı Arşivi, BEO, 4013.300914.001

Başbakanlık Osmanlı Arşivi, BEO, 004017.301212.002

Başbakanlık Osmanlı Arşivi, BOA.M.V.001162.00083.001

Başbakanlık Osmanlı Arşivi, BEO.004017.301212.001

Başbakanlık Osmanlı Arşivi, BOA, BEO, 004019.301364.001

Başbakanlık Osmanlı Arşivi, BOA, BEO, 004019.301364.002

Başbakanlık Osmanlı Arşivi, BOA, BEO, 004025.301862.002

Başbakanlık Osmanlı Arşivi, BOA, BEO, 004025. 3012862. 001

Başbakanlık Osmanlı Arşivi, BOA, BEO, 004025.301862.003

Başbakanlık Osmanlı Arşivi, BOA, DH.MTV. D.: 48/1,12

Başbakanlık Osmanlı Arşivi, BOA, DH.EUM.MEM., D.: 10/12

Başbakanlık Osmanlı Arşivi, BOA, DH.EUM.MEM.00010.00014. 001 ve 003

Başbakanlık Osmanlı Arşivi, BOA, DH.EUM.MH., D.: 34/20

Başbakanlık Osmanlı Arşivi, BOA, DH.EUM.MH., D.: 246/44

Başbakanlık Osmanlı Arşivi, BOA, DH.EUM.THR., D.: 101/70

Başbakanlık Osmanlı Arşivi, BOA, DH.EUM.LVZ., D.: 8/77 
Başbakanlık Osmanlı Arşivi, BOA, DH.MH., D.: 35/21-22-23

Başbakanlık Osmanlı Arşivi, BOA, DH.İD.00019.2.00061.002

Başbakanlık Osmanlı Arşivi, BOA, DH.EUM.MH., 0035. 0037.004

Başbakanlık Osmanlı Arşivi, BOA, DH.ID. 17-6/65

Başbakanlık Osmanlı Arşivi, BOA, ID, D: 17-6/65

Başbakanlık Osmanlı Arşivi, BOA, DH.EUM.MH., D: 86/107

Başbakanlık Osmanlı Arşivi, BOA DH.HMŞ.00022.00003.002

Başbakanlık Osmanlı Arşivi, BOA, DH. İD. 17-6/65 ve DH.EUM.LVZ. 22/66

Başbakanlık Osmanlı Arşivi, DH.HMŞ. 00022.00003.001

Başbakanlık Osmanlı Arşivi, BOA DH.HMŞ. 00022.00003.004

Başbakanlık Osmanlı Arşivi, BOA DH.HMŞ. 00022.00003.003

\section{Kitaplar}

Aydar, O. (1948), Uçan Süvariler, Ulus Basımevi, Ankara.

Hava Kuvvetleri Komutanlığı. (2009), Filo Tarihçeleri, Cilt: 1, Hava Basımevi, Ankara.

İlmen, S. (1947), Türkiye'de Tayyarecilik ve Balonculuk Tarihi, Hilmi Kitabevi, İstanbul.

İskora, M.M. (1944), Erkân-1 Harbiye Tarihçesi, Harp Akademisi Matbaas1, Ankara.

Kapucu, D. (2015), 1909-1939 Yılları Arasında Yapılan Yurtiçi ve Yurtdışı Askerî Hava Seyahatleri, Yıldırım Beyazıt Üniversitesi Sosyal Bilimler Enstitüsü, Yayınlanmamış Yüksek Lisans Tezi, Ankara.

Kansu, Y.- Şensöz, S.-Öztuna, Y. (2006), Havacıllk Tarihinde Türkler 1, Hava Kuvvetleri Basımevi, Ankara.

Kurter, A. (2009), Türk Hava Kuvvetleri Tarihi, Cilt:I, Hava Kuvvetleri Komutanlığı, Hava Basımevi, Ankara.

Kline, S. (2002), Türk Havacılık Kronolojisi, Dönence Yayınevi, İstanbul.

Kural, F. (1974), Kuruluş Yıllarında Türk Askerî Havacıllı̆ı Belgeleri (19091913), Ankara.

Keyüsk, M. (1951), Türk Havac1lık Tarihi I (1912-1914), Eskişehir. 
Kocatürk, U. (1999), Atatürk'ün Fikir ve Düşünceleri, Atatürk Araştırma Merkezi, Ankara.

Okyar, F. (1980), Üç Devirde Bir Adam, Tercüman Yayınları, İstanbul.

Özkurt, F. (2017), Gazi Mustafa Kemal Askerî Manevra ve Tatbikatlar (19091938), Genelkurmay Basımevi, Ankara,

Primi, G. (Tarihsiz), Les Ailes Turgues, Zellith Freres Yayınevi, İstanbul.

Uçarol, R. (1974), Hava Harp Okulu Tarihçesi, Hava Harp Okulu Basımevi, İstanbul.

\section{Makaleler}

Borak, S. (Mayıs 1965), “Atatürk Niçin Uçağa Binmezdi”, Hayat Tarih Mecmuası, Cilt 1, Sayı: 4

Gediz, E. "Türk Hava Kuvvetleri Tarihi”, Uçan Türk $\quad$ Dergisi, $\quad$ Türk $\quad$ Hava Kurumu Basımevi, Say1: 313, Cilt: 32

İhsanoğlu, E. (1995), “Osmanlı Havacılığına Genel Bir Bakış”, Çağını Yakalayan Osmanl1, İstanbul.

Kurt, E. (Haziran 2010) "Türk Hava Kuvvetlerinin Doğuş Yılları (1909-1914)”, Hava Kuvvetleri Dergisi, Say1: 365.

Karacagil, Ö.K. (2013), "Süreyya (Paşa) İlmen ve Serbest Cumhuriyet Frrkası" Tarih Dergisi, Say1: 57 (2013/1), İstanbul.

Türkmen, Z. TDV İslam Ansiklopedisi, Cilt: 27.

Yalçın, O. (2015), "Türk Hava Kuvvetleri Tarihinde Hava Okulu ve Hava Harp Okulu'na Geçiş Süreci”, Gazi Akademik Bakış Dergisi, C. 9, Sayı:17, Ankara.

\section{Süreli Yayınlar}

Ceride-i Askeriye, No.: 2, 21 Mart 1912 (8 Mart 1328)

Cumhuriyet Gazetesi, 27 Nisan 2000

Hürriyet Gazetesi, 29 Nisan 2000

İkdam, "Dünkü Hadise”, 12 Haziran 1913

İkdam Gazetesi, 6 Ağustos 1913

Resimli Kitap Mecmuası, No.: 15, Aralık 1909 
Resimli Kitap Mecmuas1, No.: 15, Kanunuevvel 1325/Aralık 1909

Sabah Gazetesi, 17 Mart 1912

Sabah Gazetesi, 19 Mart 1912

Sabah Gazetesi, "Resmî Beyanname", 12 Haziran 1913

Sabah Gazetesi, 28 Mart 1912

Sabah Gazetesi, 28 Nisan 1912

Sabah Gazetesi, 15 Mart 1912

Sabah Gazetesi, 16 Mart 1912

Tanin Gazetesi, 13 Aralık 1909

Tanin Gazetesi, 13 Aralık 1909

Tanin Gazetesi, "Beyanname", 12 Haziran 1913

Tanin Gazetesi, 29 Mayıs 1909

Tanin Gazetesi, 19 Mart 1912

Tanin Gazetesi, 28 Nisan 1912

Tanin Gazetesi, 18 Mart 1912

Tasvir-i Efkâr Gazetesi, 30 Mayıs 1909

Tasvir-i Efkâr Gazetesi, 3 Kanunuevvel 1909

Tasviri Efkâr Gazetesi, 3 Kanunuevvel 1909

Tasvir-i Efkâr Gazetesi, 11, 13, 15 Aralık 1909

Tasvir-i Efkâr Gazetesi, 13 Kanunuevvel 1909

Tasvir-i Efkâr Gazetesi, 13, 15 Aralık 1909

Tasviri Efkâr Gazetesi, 18 Nisan 1913

Tasviri Efkâr Gazetesi, 19 Mayıs 1913

Takvimi Vakayı Gazetesi, No: 1847, 1 Haziran 1330

Türkiye Gazetesi, 27 Nisan 2000 


\section{Ekler}

\section{EK-A}

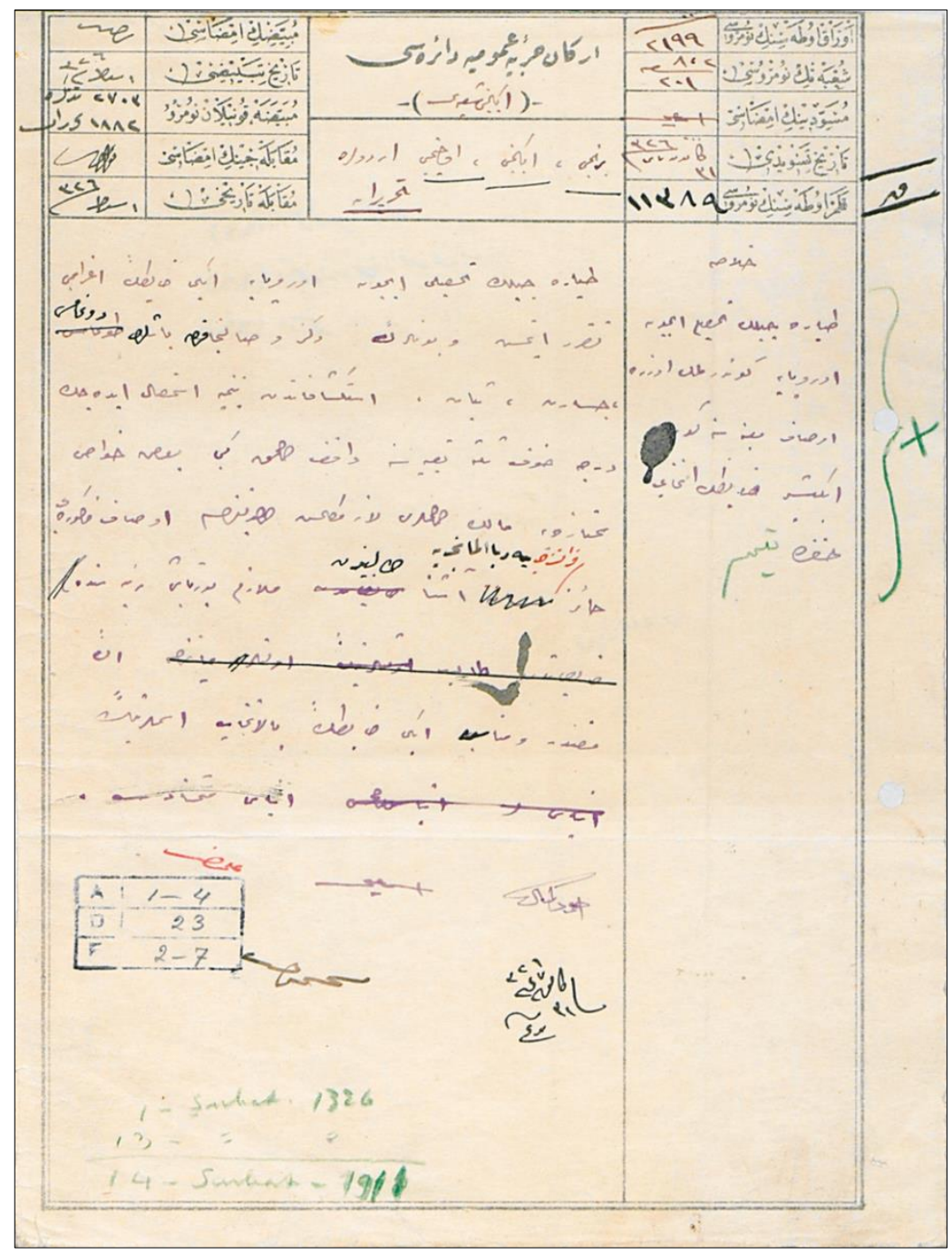

ATASE Arşivi, Klasör: 328, Dosya: 2319, Fihrist: 2-7

Tayyarecilik tahsili için Avrupa'ya gönderilmek üzere ikişer subayın Ordular tarafından belirlenerek, bildirilmesi için Osmanlı Erkan-ı Harbiye Dairesi tarafından Yayımlanan 13 Şubat 1911 tarihli ilk belge. 


\section{EK-B}

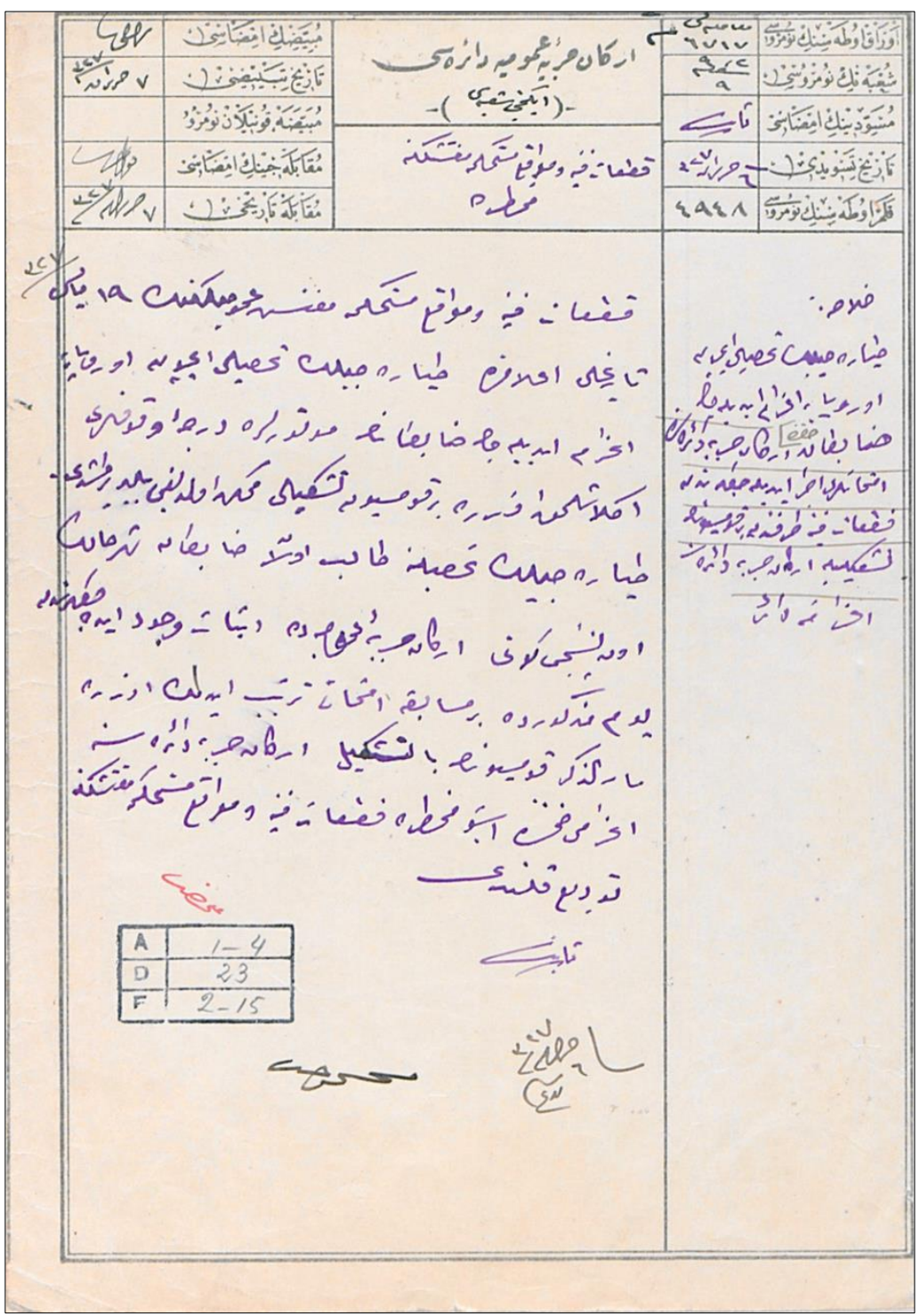

ATASE Arşivi, Klasör: 328, Dosya: 2319, Fihrist: 2-15 
EK-C: 1 Haziran 1911 (19 Mayıs 1327) tarihinde Tayyarecilik faaliyetleri ve Avrupa'ya gönderilecek personelin seçimi için Kıtaatı Fenniye Müfettişliği tarafından bir komisyon teşkiline karar verildiğine dair belge.

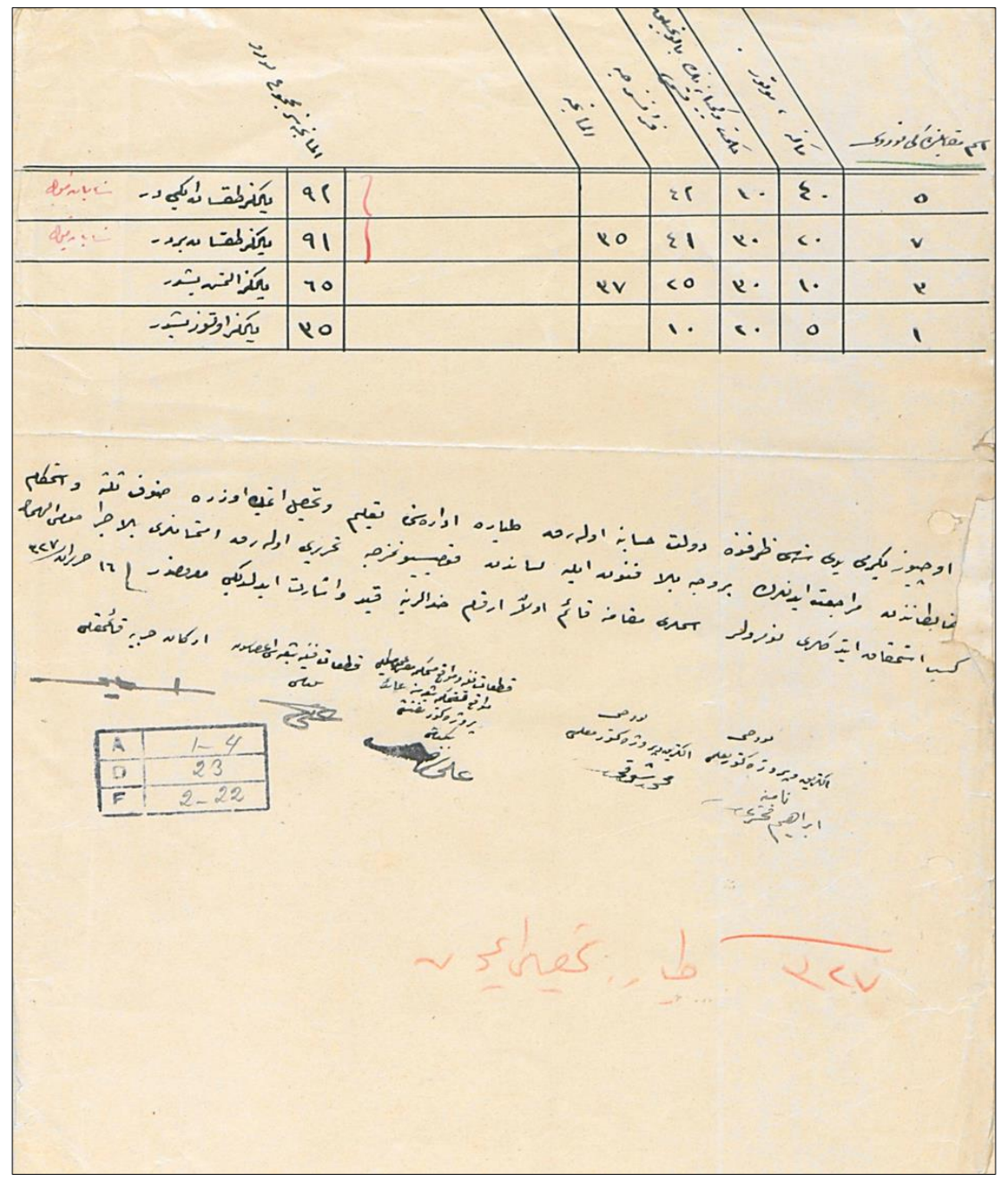

ATASE Arşivi, Klasör: 328, Dosya: 2319, Fihrist: 2-22

Kurmay Yarbay İsmail Bey Başkanlığında oluşturulan İlk Tayyare Komisyonu üyeleri tarafından Avrupa'ya gönderilecek personelin motorlara ve yabancı lisana hâkimiyetlerine dair yapılan sınav sonuçlarına dair bilgileri içeren belge. 